\title{
LA REINTERPRETACIÓN CONSTITUCIONAL DEL FUERO DE GUERRA O MILITAR EN EL MARCO DEL ESTADO DEMOCRÁTICO*
}

\author{
THE CONSTITUTIONAL REINTERPRETATION \\ OF WAR OR MILITARY COURTS \\ UNDER THE DEMOCRATIC STATE
}

\begin{abstract}
Susana Thalía PEDROZA DE LA LLAVE**
RESUMEN: Este trabajo pretende proporcionar una visión objetiva e imparcial sobre el marco jurídico que prevalece hoy en día respecto del fuero de guerra, militar o castrense en los países democráticos. Además, se abordaran temas como el origen del término fuero; el marco jurídico del fuero de guerra o militar de diversos países; para señalar que Constituciones reconocen la igualdad entre los seres humanos y el fuero militarse; asimismo se analizará el caso de México, donde la interpretación de la Suprema Corte de Justicia de la Nación supri-

ABSTRACT: This work is intended to provide an objective and impartial legal framework that prevails today in respect of military law, military or military in democratic countries. In addition, issues such as the origin of the term jurisdiction, the legal framework of the court martial or military of various countries, to show that constitutions recognize the equality of human beings and the military courts; also will analyze the case of Mexico, where the interpretation of the Supreme Court of the Nation suppresses the court martial.
\end{abstract} me el fuero de guerra.

Palabras claves: tribunales militares, Constitución, derechos humanos, Corte Interamericana de Derechos Humanos, interpretación constitucional, constitucionalismo.

* Agradezco el invaluable apoyo de Carolina Miranda Luévano para el desarrollo de este trabajo.

** Investigadora del Instituto de Investigaciones Jurídicas de la Universidad Nacional Autónoma de México. 


\section{CONSIDERACIÓN INTRODUCTORIA}

Este trabajo pretende proporcionar una visión objetiva e imparcial sobre el marco jurídico que prevalece hoy en día respecto del fuero de guerra, militar o castrense en los países democráticos.

Así, en primer lugar, me referiré al inicio del término fuero, a la época en que surge el Estado constitucional, liberal, moderno o de derecho en donde se estableció el derecho fundamental o principio universal de igualdad entre los hombres y, por otro lado, que los militares deben subordinarse estrictamente al poder civil, es decir, estar bajo su mando.

También veremos cuál es el marco jurídico de diversos países respecto del fuero de guerra o militar, en donde aún los militares son juzgados por sus propios tribunales, en donde dicho fuero puede serlo tanto por la persona como por la materia. Pero a ese respecto la Corte Interamericana de Derechos Humanos ha abierto el debate y emitido resoluciones en donde determina que se realicen reformas legales, para que los militares que atenten contra los derechos humanos sean juzgados por los tribunales civiles.

Asimismo, se analizará cuál es la interpretación de las normas constitucionales que establecen el derecho de igualdad entre los seres humanos y el fuero militar, así como cuáles son las Constituciones que le dan participación al Poder Judicial, y las que restringen o ya no contemplan dicho fuero.

A ese respecto, entonces cabe la reflexión o pregunta ¿si el fuero de guerra o militar es característico de una vieja Constitución autoritaria o por decirlo de otra forma con matices absolutistas, siendo que hoy en día deben prevalecer nuevos sistemas democráticos o Estados constitucionales democráticos y de derecho a partir de que se ha iniciado un proceso de transición jurídica o democrática? A ese respecto, entonces cabe la reflexión o pregunta si el fuero de guerra, o comúnmente llamado militar, es un resquicio característico de una vieja Constitución autoritaria a pesar de que hoy en día prevalecen nuevos sistemas democráticos.

En segundo término, se aborda de manera breve el caso particular de México, en donde de conformidad con el artículo 13 constitucional y con las tesis de la SCJN, si un militar comete un delito del orden común o federal en el ejercicio de sus funciones, o con motivo de éstas (ejemplo, homicidio o privación del derecho a la vida, violación o atentados a la integridad física o sexual, robo y daño en propiedad ajena, entre otros), debe ser juzgado por los tribunales militares. 
De acuerdo con lo señalado por la SCJN "interpretarlo de otra manera equivale a suprimir el fuero de guerra", dado que ese fuero se estableció para que los militares sean juzgados, siempre y cuando cometan un delito contra la disciplina militar, por los tribunales militares, mientras que "sujetarlos a una autoridad civil sería contrario a la interpretación correcta del artículo constitucional citado". Incluso, la SCJN ha ido más allá señalando que basta con que el militar se encuentre como miembro activo, para ser sometido a la jurisdicción militar. Con ello vemos que la interpretación constitucional del fuero de guerra o militar no es acorde con lo señalado en la época en que surge el Estado constitucional o moderno, ya que entonces los militares no se subordinan al poder civil ni son gobernados por el mismo, ni se respetan diversos principios de la Constitución como el de igualdad, pero por disposición del Poder Judicial, como es nuestro caso. Sin embargo, en julio de 2011 la SCJN cambió la interpretación anterior y ya se ajusta a lo expresamente señalado por la Constitución en el artículo 13 de la misma.

Por ello, cabe nuevamente la reflexión o pregunta planteada líneas arriba en el entendido de que si hoy en día deben prevalecer los nuevos sistemas democráticos ¿el fuero de guerra o militar es característico de una vieja Constitución autoritaria?

Por último, se abordarán las conclusiones y perspectivas a las que llega la autora de este trabajo respecto a la necesaria reinterpretación constitucional del fuero de guerra en el marco de un Estado democrático por parte de los Poderes Legislativo y Judicial, en donde derivado del análisis del derecho comparado se presentan varias opciones en esta materia.

\section{EL FUERO DE GUERRA O MILITAR EN LOS PAÍSES DEMOCRÁTICOS}

Es necesario considerar, en principio, que el fuero de guerra, militar, castrense o jurisdicción especializada, ${ }^{1}$ en cualquier país, es un tema que no ha sido muy desarrollado desde el punto de vista jurídico, y los tratados internacionales de derechos humanos tampoco lo abordan específicamente, por lo que para su conocimiento se tiene que realizar un ejercicio de inter-

1 Como jurisdicción especializada así la llama González Oropeza, Manuel, "El Fuero Militar en México: la injusticia de las Fuerzas Armadas, México, Revista Lex, junio de 2006, p. 41. 
pretación armónica de las disposiciones que existen en torno a éste ${ }^{2}$ y sus antecedentes histórico-jurídicos.

Así, en su inicio, ${ }^{3}$ el "fuero"4 en los tiempos de Roma con el Digesto significaba que los soldados tenían que ser juzgados por sus jefes a cuyas órdenes militaban, sin embargo, por otros delitos ajenos a la disciplina eran juzgados por el presidente de la Provincia. ${ }^{5}$

Con la Carta Magna de Juan Sin Tierra de 1215 se consagró el principio de juicio por pares, entendido en Iberoamérica como una justicia privilegiada de determinada clase social. ${ }^{6}$

Después, el fuero militar consistió en una ley excepcional o en un privilegio concedido por los Reyes a ciertos hombres como un halago por ocupar tierras conquistadas y, posteriormente, adquirió el significado de orden de excepción. Así, en España el término "fuero" tuvo una connotación especial. En la reconquista "fue necesario halagar a quienes quisieran poblar determinadas regiones de la península, para lo que se otorgaron concesiones, privilegios y mercedes a las villas". ${ }^{7}$ De tal forma, en el derecho español se identificó la idea de privilegio con la de fuero. Por ello, los tribunales especiales muestran desigualdad, un procedimiento complicado, incluso, en algunos territorios de España existían hasta 15 fueros. Es así que el fuero se plasma en un estado absolutista.

Más adelante, con las ideas de los revolucionarios franceses que tienen también impacto en España y en Norteamérica, se va socavando el abso-

2 Cfr. Esponda, Jaime, "Apuntes preliminares sobre tema de jurisdicción militar", Los tribunales militares y la Constitución, 3-9, Colección Cuadernos de Derechos Humanos, Guatemala, Procurador de los Derechos Humanos, 1996, p. 45.

3 Si se desea profundizar sobre la historia del fuero de guerra, consúltese Calderón Serrano, Ricardo, "El Fuero de Guerra”, Criminalia. Revista de Ciencias Penales, México, año VII, número 12, agosto de 1941, pp. 737-755.

4 Para la Real Academia Española la palabra "fuero" deriva del latín forum - foroy significa cada uno de los privilegios y exenciones que se conceden a una provincia, ciudad o a una persona, así como privilegio, prerrogativa o derecho moral que se reconoce a ciertas actividades, principios, virtudes, entre otras, por su naturaleza, para señalar situaciones de privilegio derivadas de la condición social de las personas, en donde existen un conjunto de órganos jurisdiccionales creados ex profeso para ciertas personas o corporaciones, $c f r$. Suprema Corte de Justicia de la Nación, Serie Grandes temas del constitucionalismo mexicano. El fuero, México, 2005, pp. 9, 10 y 19.

5 Cfr. Rebollo Moreno, Enrique, "Fuero de guerra", Boletín Jurídico Militar, México, tomo XIX, números 9 y 10, septiembre-octubre de 1955, pp. 41-421.

6 Cfr. Suprema Corte de Justicia de la Nación, op. cit., pp. 9, 10 y 95.

7 Ibidem, p. 9. 
lutismo en el siglo XVIII. ${ }^{8}$ Es en esta época cuando se da el surgimiento del Estado constitucional, liberal o moderno o de derecho, y en donde particularmente la Declaración de Derechos del Buen Pueblo de Virginia de 1776 señaló que ningún hombre, o grupo de hombres, tienen derecho a emolumentos exclusivos o privilegiados de la comunidad, "sino en consideración a servicios públicos", y que una milicia bien regulada, compuesta del cuerpo del pueblo entrenado para las armas, es la defensa apropiada, natural y segura de un estado libre; que en tiempos de paz, los ejércitos permanentes deben evitarse por peligrosos para la libertad; y que en todos los casos, los militares deben subordinarse estrictamente al poder civil, y ser gobernados por el mismo, ${ }^{9}$ es decir, estar bajo su mando. A ese respecto, es conveniente citar a Samuel Huntington quien considera, cito: "el control civil subjetivo se refiere a aumentar el poder civil sobre el poder militar, para lo cual deben semejarse al máximo los militares a los civiles; en otras palabras, el control militar subjetivo alcanza sus fines haciendo más civiles a los militares". ${ }^{10}$

Asimismo, la Declaración de Independencia de los Estados Unidos de 1776 consideró mal una situación y por ello plasmó la siguiente acusación al rey de la Gran Bretaña: "Ha atentado a la libertad civil de los ciudadanos, manteniendo en tiempo de paz entre nosotros tropas armadas, sin el consentimiento de nuestra legislatura: procurando hacer al militar independiente y superior al poder civil".

Por otra parte, y en el mismo siglo, la Declaración Francesa de los Derechos del "Hombre" y del "Ciudadano" de 1789 señaló que "habían de considerarse iguales aquellos a quienes la ley considerara como tales y diferentes aquellos otros a quienes la ley diferenciara"; que todos los hombres nacen y permanecen libres; iguales en derechos; todos los ciudadanos, siendo iguales... son igualmente admisibles a todas las dignidades, puestos y empleos públicos, según su capacidad, y sin otra distinción que la de sus virtudes y talentos. ${ }^{11}$ También señaló en su artículo 16 que: “Toda sociedad

Ibidem., pp. 9 y 10.

9 Cfr. Hervada, Javier y José M. Zumaquero, Textos internacionales de Derechos Humanos, Pamplona, Universidad de Navarra, 1978, pp. 26 y ss.

${ }^{10}$ Instituto Latinoamericano de Cooperación Tecnológica y Relaciones Internacionales, Graf Von Baudissin, Wolf, "Prólogo", Fuerzas Armadas y democracia, Buenos Aires, El Cid Editor, 1982, p. 369.

11 Cfr. Hervada, Javier y José M. Zumaquero, op. cit., pp. 46 y ss. 
en la que no esté asegurada la garantía de los derechos, ni determinada la separación de los poderes no tiene Constitución". ${ }^{12}$

Así, como todos saben, con los anteriores documentos se deja atrás el absolutismo y se sientan las bases para el surgimiento del constitucionalismo y del Estado de Derecho, siendo una de sus características los principios de igualdad y de la división del poder, y la separación entre el poder civil y el poder militar, dando primacía al primero en cuanto poder político. Se observa que durante esa época los principios de la jurisdicción militar ya resultaban incompatibles con los postulados de la igualdad ciudadana. Por ello, en Francia en 1790 se estableció sólo la competencia de la jurisdicción por razón de la materia, en donde le correspondía a los tribunales militares conocer de los delitos relacionados con la disciplina militar, y en 1792 se determinó que de los crímenes conocerían los tribunales colegiados. Lo mismo ocurrió en Italia en donde se reducía la competencia del tribunal militar al delito militar. ${ }^{13}$

En ese siglo, se consideró también que los Ejércitos son un brazo del Ejecutivo y, por ello, deben subordinarse también a dicho Poder como un instrumento pasivo en manos del Gobierno. ${ }^{14}$ Sin embargo, pese a los movimientos de Independencia o revolucionarios no todos los fueros y privilegios desaparecieron. En España, al expedirse la Constitución de Cádiz de 1812, los fueros quedaron abolidos pero nominalmente, ya que se conservó el fuero de los legisladores y el de los Cuerpos de la Casa Real (militares encargados de velar por el rey, con un Tribunal Supremo de Guerra y Marina), y tras la independencia se suprimieron unos y se crearon otros. Por ejemplo, en México, incluso con la Constitución liberal de 1857, Benito Juárez dejó subsistente el fuero de imprenta, el de los legisladores y el militar. ${ }^{15}$

A pesar de que Francia siguió por un camino distinto respecto de los fueros, en muchos otros países los fueros de excepción en tiempo de paz se toleraron por las constituciones, interpretándose no sólo en razón de la materia, sino en razón de la persona. Interpretarse en razón a la materia "quiere decir que los únicos actos que deben juzgarse ante esos tribunales,

12 Ibidem, pp. 46 y 52.

13 Cfr. Calderón Serrano, Ricardo, op. cit., pp. 745 y 746.

14 Cfr. Fernández Segado Francisco, "La posición constitucional de las fuerzas armadas en España. Reflexiones entorno al artículo 8 de la Constitución de 1978", Revista Derecho PUC, Lima, núm. 49, diciembre de 1995, p. 37.

15 Cfr. Suprema Corte de Justicia de la Nación, op. cit., pp. 10, 11 y 14. 
son los actos de tipo castrense o los que atentan contra la disciplina militar, pero no los actos ilegales del derecho común cometidos por los militares... desechándose desde ya, la interpretación de que la sola pertenencia a la institución convierte en militar a cualquier acto...". ${ }^{16}$ En este contexto, algunos países presentan una regresión al estado absolutista o plasman una norma autoritaria en lugar de plasmar una norma democrática apegada a los postulados del siglo XVIII.

En este sentido, desde el punto de vista histórico, las doctrinas jurídicomilitares se han clasificado en tres grupos desde que, a su vez, se consideran representados por las siguientes tendencias:

La francesa: de unificación del Poder Judicial con tendencia a la reducción de la esfera de competencia de la jurisdicción militar y encuadramiento de sus tribunales, por lo menos en su última instancia dentro de la órbita de la justicia común; la germana, que propugna la necesidad de una jurisdicción militar sin límite de conocimiento y tribunales propios y autónomos, y la intermedia o italiana, que conserva la jurisdicción restringiéndola en cuanto a su actividad a motivos representados por la condición de la persona responsable, la materia, la ocasión y el lugar y ejercida por elementos destacadamente militares. ${ }^{17}$

Hoy en día, en este contexto, podemos afirmar que existe un cuarto grupo desde el punto de vista histórico y de las doctrinas jurídico-militares, considerándose como tendencia, y derivado de la lucha por los derechos humanos que se ha orientado en el sentido de lograr el constreñimiento de fuero a las materias estrictamente militares ${ }^{18} \mathrm{y}$ no por la persona, y que el poder militar quede sujeto al poder civil, en donde por cierto, no se da el paso completo, sino sólo se establece como excepción algunos delitos que cometen los militares y que pueden ser conocidos por los tribunales ordinarios. La primera responsabilidad de las instituciones armadas ante los derechos humanos, es que éstas son las depositarias de la fuerza que el Estado resuelve emplear en apoyo de su política internacional o frente a conmociones o problemas

16 García Laguardia, Jorge Mario, "Los tribunales militares y la Constitución”, Los tribunales militares y la Constitución, 3-9, Colección Cuadernos de Derechos Humanos, Guatemala, Procurador de los Derechos Humanos, 1996, pp. 10 y 11, quien cita al constitucionalista peruano Alberto Borea Odria.

17 Calderón Serrano, Ricardo, op. cit., p. 753.

18 Cfr. García Laguardia, Jorge Mario, op. cit., p. 10, quien cita al constitucionalista peruano Alberto Borea Odria. 
internos. El empleo de esos instrumentos no puede hacerse sin sujeción a una ética universal representada en los derechos humanos de la población no combatiente. ${ }^{19}$ Un soldado es un ciudadano que opta por servir al Estado en otras funciones, ${ }^{20}$ tiene la obligación de respetar los derechos humanos, debe tener conciencia de estos valores y haberlos experimentado propiamente para poder garantizarlos y defenderlos, ${ }^{21} \mathrm{y}$ debe someterse a las leyes con las mismas responsabilidades y exigencias que cualquier ciudadano en cualquier país (es un principio universal la igualdad entre las personas), en donde las leyes y los tribunales deben ser los mismos para toda la sociedad y no ser considerado como parte de un grupo social con privilegios.

Así, de acuerdo con Vittorio Bachelet, el espíritu democrático de la República significa afirmar "la plena sujeción del ordenamiento castrense al ordenamiento estatal democrático y recordar que el ordenamiento militar debe fundarse sobre la dignidad de la persona humana y sobre el pleno respeto de los derechos garantizados por la Constitución". ${ }^{22}$

"Aun cuando existen normas generales en materia de interpretación de las leyes; hay que tomar en cuenta que sobre la interpretación constitucional, se deben seguir ciertos principios, a fin de que el texto sea algo vivo y que responda a las expectativas que el Poder Constituyente plasmó en el mismo". ${ }^{23}$ "Interpretar una norma jurídica implica indagar sobre su sentido, sus alcances y sus relaciones con otras normas del orden jurídico". ${ }^{24}$ En el ámbito del derecho constitucional comparado se han propuesto las siguientes reglas de interpretación constitucional:

1. Debe prevalecer el contenido finalista de la Constitución, el cual es garantizar la libertad y la dignidad humana;

2. Debe ser interpretada con un criterio amplio, liberal y práctico;

19 Cfr. Cerdas Cruz, Rodolfo y Nieto Loaiza, Rafael (comps.), Cançado Trindade, Antonio A., Pról. Estudios Básicos de Derechos Humanos I, San José, Costa Rica, Instituto Interamericano de Derechos Humanos, 1994, pp. 314, 317 a 319 y 323.

${ }^{20}$ Cfr. Fundación Friedrich Naumann de la República Federal de Alemania. Función del ejército en una sociedad democrática, Guatemala, Fundación Friedrich Naumann de la República Federal de Alemania, 1995, p. 74.

21 Ibidem, p. 105.

22 Ibidem, p. 67.

${ }^{23}$ García Laguardia, Jorge Mario, op. cit., p. 15.

24 Idem. 
3. Las palabras de la Constitución deben ser interpretadas en su sentido general común;

4. Debe ser interpretada como un conjunto armónico;

5. Se deben considerar la situación social, económica y política que existen en el momento de realizar la interpretación, y

6. Las excepciones y privilegios deben interpretarse con un criterio restrictivo. ${ }^{25}$

Finalmente, y respecto de la interpretación, el principio fundamental del control constitucional es el principio de supremacía de la Constitución, que se refiere a que ésta prevalece sobre cualquier ley (o Código) y sanciona con nulidad aquella norma que viole o tergiverse una norma constitucional. ${ }^{26}$

Un argumento más a considerar, además del principio de igualdad ante la ley, es el principio esencial de la organización política, el cual es la división del poder, consistente en que el Ejecutivo, Legislativo y Judicial se deben ocupar de lo que es materia de su competencia. Así, las Fuerzas Armadas dependen del Poder Ejecutivo, por lo que no tienen como función propia la de administrar, incluso, procurar justicia, sino que la primera le corresponde al Poder Judicial, respetando el principio del debido proceso penal y debe existir la independencia e imparcialidad de los jueces. ${ }^{27}$

Sin embargo, por mucho tiempo, en diversos países y, sobre todo, de América Latina, se mantuvo la idea de esperar la reforma a las leyes que determinan que los militares, por el sólo hecho de serlo, deben ser juzgados por los militares, cuando también es una tarea del Poder Judicial el vigilar la validez constitucional de las normas en vigencia y, además, ya es considerada como una exigencia internacional para que se modifique el derecho interno de los países. ${ }^{28}$

Dentro del sistema político, los instrumentos militar y policial deben depender de la autoridad civil y actuar encuadrados en un orden jurídico cuyas bases se asienten en la Constitución. En este contexto no existe otra alternativa que la subordinación de las instituciones militares al poder civil, lo que implica la dependencia real respecto del Poder Ejecutivo y, por

25 Ibidem, pp. 15 y 16, citando este autor a Segundo Linares Quintana.

26 Ibidem, p. 16.

27 Cfr. Menchú Tum, Rigoberta, "Fundamentación jurídica en el caso de la masacre de Xaman”, Los tribunales militares y la Constitución, cit., pp. 26 y 29.

28 Cfr. Menchú Tum, Rigoberta, op. cit., 1996, p. 26. 
consiguiente al control parlamentario, ${ }^{29}$ cuya tarea de control no puede considerarse como agraviante, sino que se ejerce sobre el funcionamiento de todas las organizaciones que forman parte del Estado, ${ }^{30}$ y también sujetas al Poder Judicial.

No obstante, de tener vigencia los procedimientos legales del fuero militar, sin menoscabo de la disciplina, se deben abordar y corregir, definiendo con extremo cuidado y precisión sus límites. ${ }^{31}$

En un proceso de transición a la democracia o transición jurídica, como el iniciado a nivel internacional durante finales de los años setenta y principios de los ochenta, la democracia se reparte a lo largo del tiempo que dure la misma, democratizándose, en primer lugar, las instituciones que resultan más fáciles, y en último lugar aquellas que presentan más dificultad para asumir los cambios. Así, por ejemplo, el proceso democratizador en España se ha repartido durante los años que ha durado la transición, realizándose la democratización de las instituciones, y finalmente, la de las fuerzas armadas. ${ }^{32}$

En España se optó como prioridad el acatamiento a la Constitución y, lo que es más importante, el límite de la obediencia debida, pues lo tradicional era entender la obediencia militar como una obediencia ilimitada, y en 1978 se cambió la concepción tradicional y se ajustó a la jurisprudencia del Tribunal de Nüremberg, según la cual las órdenes que entrañan delito no deben ser obedecidas. Se permitió al fiscal apelar las sentencias de los tribunales militares ante el Tribunal Supremo (civil). Se dio la disminución del número de alumnos que ingresan anualmente en las academias militares. Se ha procurado reconducir a las fuerzas armadas a sus tradicionales cometidos, liberándolas de las actividades políticas, policiales y judiciales que habían asumido durante la dictadura. ${ }^{33}$ Asimismo, la jefatura supre-

29 Cfr. Schaposnik, Eduardo C. La democratización de las Fuerzas Armadas venezolanas, Caracas, Venezuela, 1985, p. 175.

${ }^{30}$ Cfr. Instituto Latinoamericano de Cooperación Tecnológica y Relaciones Internacionales, op. cit., p. 368.

31 Cfr. Lara Villa, Samuel, "Las fuerzas armadas mexicanas en el proyecto inaplazable de Reforma del Estado”, en Revista del Senado de la República, México, vol. 5, núm. 6, julio-septiembre de 1999, p. 238.

${ }^{32}$ Cfr. Busquets, Julio, "Las Fuerzas Armadas en la transición española", Sistema, Revista de Ciencias Sociales, Madrid, núm. 93, noviembre de 1989, p. 24.

33 Ibidem, pp. 21, 22, 25, 26 у 28. 
ma de esas Fuerzas Armadas se atribuye a quien es cabeza del Estado y garante de su Constitución, esto es, al rey. ${ }^{34}$

Así, específicamente en ese país, el artículo 117.5 de la Constitución Española vigente señala que la ley regulará el ejercicio de la jurisdicción militar en el ámbito "estrictamente castrense", y se prohíben los tribunales de excepción. Es decir, que dicho país se ubica en la tendencia francesa.

Sobresale que, en la cúspide de la jurisdicción militar, se instala en el Tribunal Supremo con una Sala de lo Militar, con competencia para resolver determinados recursos. Se mantiene y fortalece la jurisdicción militar relacionada con los valores y el cumplimiento de la disciplina militar. ${ }^{35} \mathrm{Di}$ cha Sala está integrada por cuatro magistrados ordinarios o civiles y cuatro miembros del cuerpo jurídico militar. ${ }^{36}$

Además, la jurisprudencia constitucional ha reducido a límites muy estrechos el posible ámbito competencial de la jurisdicción militar, señalando que este artículo 117.5 impide al legislador atribuir arbitrariamente a los órganos de la jurisdicción militar el conocimiento de delitos ajenos al ámbito estrictamente castrense. Y, de forma determinante, señala que lo estrictamente castrense sólo puede ser aplicado a los delitos exclusiva y estrictamente militares, tanto por su directa conexión con los objetivos, tareas y fines propios de las Fuerzas Armadas, es decir, los que hacen referencia a la organización bélica del Estado, indispensable para las exigencias defensivas de la comunidad como bien constitucional, como por la necesidad de una vía judicial específica para su conocimiento y eventual represión. ${ }^{37}$

34 Cfr. Fernández Segado Francisco, op. cit., p. 26.

35 Cfr. González Licea, Genaro, "Reflexiones sobre fuero de guerra y seguridad nacional de cara al siglo XXI", IDPF Revista del Instituto Federal de Defensoría Pública, México, núm. 3, junio de 2007, p. 47.

36 Cfr. González Licea, Genaro, op. cit., p. 47. Asimismo, consúltese Ley Orgánica 4/1987, del 15 de julio, de la Competencia y Organización de la Jurisdicción Militar (publicada en el BOE, del 18 de julio de 1987; entrada en vigor: 1o. de mayo de 1988); Ley Orgánica 13/1985, de 9 de diciembre, de Código Penal Militar (publicada en el BOE: 11 de diciembre de 1985; entrada en vigor: 1o. de junio de 1986), y Ley Orgánica 5/2005, de 17 de noviembre, de la Defensa Nacional (publicada en el BOE el 18 de noviembre de 2005; entrada en vigor: 8 de diciembre de 2005).

37 Cfr. Martí Sánchez, Sylvia, "Sinopsis del artículo 117 de la Constitución española", Congreso de los Diputados, diciembre de 2003, en línea en http://www.congreso. es/consti/constitucion/indice/sinopsis/sinopsis.jsp? art=117\&tipo=2, consultado el $10 \mathrm{de}$ octubre de 2010 . 
Como dato más reciente, en Francia la justicia militar sólo subsiste en tiempo de guerra, ya que desde 1982 se quitó tal jurisdicción. ${ }^{38}$ Por lo anterior, es considerada como uno de los países que aplica el modelo más radical toda vez que suprime esta jurisdicción especializada, entregando el juzgamiento de los delitos militares (que subsisten como delitos especiales) a la justicia civil. ${ }^{39}$

Por otra parte, en Alemania, el artículo 96 de su Ley Fundamental de 1949 señala, a grandes rasgos, que la Federación podrá crear tribunales penales militares como tribunales federales para las Fuerzas Armadas, y que éstos podrán ejercer la jurisdicción sobre miembros de las Fuerzas Armadas que hubieren sido enviados al extranjero o que estuvieren embarcados en navíos de guerra, y que la regulación se hará por una ley federal, situándose estos tribunales bajo la competencia del Ministerio Federal de Justicia. Mientras que el artículo 101 de dicha Ley Fundamental prohíbe los tribunales de excepción, pero que sólo por ley podrán ser instituidos tribunales para materias especiales. Es decir, este país se ubica en la tendencia del mismo nombre: germana.

Respecto a Italia, la Constitución de la República italiana de 1947, en su artículo 25 , señala que nadie podrá ser sustraído al juez natural establecido, y el artículo 103 de dicha Constitución menciona que los tribunales militares sólo en tiempo de guerra tendrán la jurisdicción establecida por la misma. Mientras que en tiempo de paz tendrán jurisdicción únicamente para los delitos militares cometidos por personas pertenecientes a las Fuerzas Armadas. Es decir, este país se ubica en la tendencia intermedia o italiana.

En cuanto a los países de América Latina tenemos lo siguiente.

En Chile, a través de su Constitución de 1980, se señala en su artículo 19 que a todas las personas se les asegura la igual protección de la ley en el ejercicio de sus derechos y que, tratándose de los integrantes de las Fuerzas Armadas y de Orden y Seguridad Pública, este derecho se regirá, en lo concerniente a lo administrativo y disciplinario, por las normas pertinentes de sus respectivos estatutos. Asimismo, que nadie podrá ser juzgado

38 Cfr. Dirección de Información de la Policía Nacional del Perú, “¿Qué es el Fuero Militar Policial?", Boletín Policía Nacional del Perú, año 1-2010, en línea en http:// www.pnp.gob.pe/boletin/conteudo_1/csjm.html, consultado el 21 de octubre de 2010.

39 Cfr. Mera Figueroa, Jorge, "La Modernización de la Justicia Militar un Desafío Pendiente", pp. 6 y 7, en línea en http://www.ssg.cl/justicia/documentos/mera_la_modernizacion_de_la_justicia_militar.pdf?PHPSESSID=064ea95572a300405fd9acbffoa5 Oa75, consultado el 21 de octubre de 2010. 
por comisiones especiales, sino por el tribunal que señalare la ley y que se hallare establecido por ésta con anterioridad a la perpetración del hecho.

$\mathrm{Su}$ artículo 83, párrafo 4, dispone que el ejercicio de la acción penal pública, y la dirección de las investigaciones de los hechos que configuren el delito, de los que determinen la participación punible y de los que acrediten la inocencia del imputado en las causas que sean de conocimiento de los tribunales militares, como la adopción de medidas para proteger a las víctimas y a los testigos de tales hechos corresponderán, en conformidad con las normas del Código de Justicia Militar y a las leyes respectivas, a los órganos y a las personas que ese Código y esas leyes determinen.

Por lo que concierne al Código de Justicia Militar de 1944 de ese país, en su artículo 1o. señala que la facultad de conocer en las causas civiles $\mathrm{y}$ criminales de la jurisdicción militar, de juzgarlas y de hacer ejecutar lo juzgado, pertenece exclusivamente a los Tribunales que establece ese Código. Para ello, el artículo 5o. señala que corresponde a la jurisdicción militar el conocimiento:

De las causas por delitos militares, entendiéndose por tales los contemplados en el Código, excepto aquéllos a que dieren lugar los delitos cometidos por civiles previstos en los artículos $284^{40}$ y $417,{ }^{41}$ cuyo conocimiento corresponderá en todo caso a la justicia ordinaria, y también de las causas

40 Artículo 284. El que amenazare en los términos del artículo 296 del Código Penal, ofendiere o injuriare de palabra o por escrito o por cualquier otro medio a las Fuerzas Armadas, sus unidades, reparticiones, armas, clases o cuerpos determinados, o a uno de sus integrantes con conocimiento de su calidad de miembro de esas instituciones, será sancionado con la pena de presidio menor en su grado mínimo a medio. Artículo 286. Se consideran circunstancias agravantes de los delitos considerados en los artículos 281 a 284 ser el culpable militar, o ejecutar el delito en presencia de rebeldes o sediciosos.

41 Artículo 417. El que amenazare en los términos de los artículos 296 y 297 del Código Penal a uno de los integrantes de Carabineros de Chile con conocimiento de su calidad de miembro de esa Institución, unidades o reparticiones, sufrirá la pena de presidio menor en su grado mínimo a medio. Mientras que el Código Penal, en sus artículos 296 y 207, señala lo siguiente: Artículo 296. El que amenazare seriamente a otro con causar a él mismo o a su familia, en su persona, honra o propiedad, un mal que constituya delito, siempre que por los antecedentes aparezca verosímil la consumación del hecho, será castigado:

1o. Con presidio menor en sus grados medio a máximo, si hubiere hecho la amenaza exigiendo una cantidad o imponiendo ilegítimamente cualquiera otra condición y el culpable hubiere conseguido su propósito.

2o. Con presidio menor en sus grados mínimo a medio, si hecha la amenaza bajo condición el culpable no hubiere conseguido su propósito.

3o. Con presidio menor en su grado mínimo, si la amenaza no fuere condicional; a no ser que merezca mayor pena el hecho consumado, caso en el cual se impondrá ésta. 
que las leyes especiales sometan al conocimiento de los tribunales militares y, más adelante, este Código contempla otros delitos respecto del Código Aeronáutico; también menciona que conocerán de las causas por delitos comunes cometidos por militares durante el estado de guerra, estando en campaña, en acto del servicio militar o con ocasión de él (de conformidad con el artículo 421 de este mismo ordenamiento, se entiende por acto del servicio todo el que se refiera o tenga relación con las funciones que a cada militar corresponden por el hecho de pertenecer a las Instituciones Armadas), en los cuarteles, campamentos, vivaques, fortalezas, obras militares, almacenes, oficinas, dependencias, fundiciones, maestranzas, fábricas, parques, academias, escuelas, embarcaciones, arsenales, faros y demás recintos militares o policiales o establecimientos o dependencias de las Instituciones Armadas.

No obstante lo dispuesto anteriormente, el artículo 9o. del mismo Código señala que serán juzgados por los tribunales ordinarios los militares que se hicieren reos de delitos comunes cometidos en el ejercicio de funciones propias de un destino público civil. Sobresale que el artículo 11 dispone que el Tribunal Militar tenga jurisdicción para juzgar no sólo al autor de un delito de jurisdicción militar, sino también a los demás responsables de él, aunque no estén sujetos a fuero. Finalmente, el artículo 12 dispone que cuando se hubiere cometido por un mismo agente delitos de jurisdicción militar y de jurisdicción común, que no sean conexos, el Tribunal Militar será competente para conocer de los primeros y el tribunal ordinario de los segundos. Si la aplicación de esta norma creare alguna interferencia o dificultad para la práctica de medidas o diligencias que se relacionan con el inculpado, tendrán preferencia las requeridas por el Tribunal Militar. Es decir, este país se ubica en la tendencia germana.

La Constitución Política de la República de Guatemala de 1985, en su artículo 219 señala que los tribunales militares conocerán de los delitos o

Cuando las amenazas se hicieren por escrito o por medio de emisarios, éstas se estimarán como circunstancias agravantes.

Para los efectos de este artículo se entiende por familia el cónyuge, los parientes en la línea recta de consanguinidad o afinidad legítima, los padres e hijos naturales y la descendencia legítima de éstos, los hijos ilegítimos reconocidos y los colaterales hasta el tercer grado de consanguinidad o afinidad legítimas.

Artículo 297. Las amenazas de un mal que no constituya delito hechas en la forma expresada en los números 10. o 2o. del artículo anterior, serán castigadas con la pena de reclusión menor en sus grados mínimo a medio. 
faltas cometidos por los integrantes del Ejército de Guatemala. Mientras que la Ley Constitutiva del Ejército de Guatemala de 1991, en su artículo 11 dispone que los integrantes del Ejército, comprendidos en el artículo 6o., estarán sujetos al fuero militar. Pero en ese país, en 1996, y con la presentación de una iniciativa de decreto para reformar el Código Militar, apoyada por el entonces General de División y Ministro de la Defensa Nacional, Julio Arnoldo Balconi Turcios, se estableció que la jurisdicción en los delitos o faltas esencialmente militares corresponde a los tribunales militares, pero en los casos de delitos ofaltas comunes o conexos cometidos por los militares se aplicará el Código Procesal Penal y serán juzgados por tribunales ordinarios a que se refiere la Ley del Organismo Judicial. ${ }^{42}$ Es decir, este país se ubica en la tendencia intermedia.

Así, el Código Militar Penal y de Procedimientos Respectivos de 1878, en su artículo 2 se refiere a que la jurisdicción en los delitos o faltas esencialmente militares corresponde exclusivamente a los tribunales que esta ley designa, y "en los casos de delitos o faltas comunes o conexos cometidos por militares, se aplicará el Código Procesal Penal y serán juzgados por los tribunales ordinarios a que se refiere la Ley del Organismo Judicial". Además, aun más se restringe la existencia de la competencia para los tribunales militares, ya que su artículo 10 señala que exceptúense del conocimiento de estos tribunales, en lo criminal, por pérdida de fuero, los casos siguientes: Los delitos cometidos por los militares antes de su entrada al Ejército; los cometidos durante la deserción; las contravenciones a las leyes de policía y bandos de buen gobierno; en todo caso, el hurto de semilleros, almácigos o plantíos de café y todos los demás hurtos no exceptuados por este Código, cuando hubiere reincidencia; los atentados y desacatos contra los Jueces ordinarios; los atentados injurias, insultos o amenazas de hecho o de palabra, contra los agentes de la autoridad ordinaria; las causas de contrabando o defraudación de los derechos de la Hacienda Pública; el juego prohibido, cuando se verificare en establecimientos públicos o casas particulares; las exacciones de multas y penas pecuniarias, impuestas por la jurisdicción ordinaria, cuando ésta conozca en asuntos civiles; las faltas y delitos que los Auditores cometieren en el ejercicio de la abogacía; los

42 Cfr. Balconi Turcios, Julio Arnoldo, "Propuesta de reforma al artículo 546 del Código Procesal Penal", Los tribunales militares y la Constitución, 3-9, Colección Cuadernos de Derechos Humanos, Procurador de los Derechos Humanos, Guatemala, 1996, pp. 57-59 y Procurador de los Derechos Humanos, "Decreto número 41-96", Los tribunales militares y la Constitución, cit, pp. 61 y 62. 
delitos y faltas que cualesquiera de los que disfrutan del fuero militar, cometieren con ocasión del ejercicio de algún destino y encargo públicos del orden civil; los que se cometieren por algún individuo, que hallándose en actual y efectivo servicio, estuviere vestido de paisano; los que en virtud de leyes especiales, se sujetan a un fuero privativo, y los que contravinieren a la ley de trabajadores.

La Constitución Política de la República de Honduras de 1982, en su artículo 90 reconoce el fuero de guerra para los delitos y faltas de orden militar, y fue interpretado, mediante Decreto 58-93 de 30 de marzo de 1993 y publicado en el Diario Oficial, el 2 de junio de 1993, en el sentido que se entiende por "fuero de guerra" al conjunto de normas contenidas en la legislación penal militar, a ser aplicadas por los tribunales militares a los miembros de las Fuerzas Armadas que estando de alta y en acto de servicio, incurrieren en la comisión de delitos o faltas de naturaleza "estrictamente militar", y que, en caso de conflicto de competencia en cuanto a si el delito es penal común o penal militar, prevalecerá el fuero común. Es decir, este país también se ubica en la tendencia intermedia.

Asimismo, y en cuanto al Código Penal Militar de 1906, éste establece en su artículo 14 que toda persona responsable criminalmente de un delito o falta, lo es también civilmente con sujeción a los preceptos de la legislación común, en cuanto ésta sea aplicable al orden militar. Particularmente, el artículo 310 dispone que corresponde a la jurisdicción militar el conocimiento de las causas por delitos militares, y el artículo 311 que, sin embargo, la jurisdicción común podrá iniciar los procesos por delitos militares, instruyendo las primeras diligencias, las cuales se limitarán a proteger a los perjudicados, a detener a los presuntos delincuentes, a consignar las pruebas que conduzcan a la comprobación del delito y de sus autores, y a recoger y conservar los instrumentos u objetos concernientes al hecho. Finalmente, el artículo 6o. de la Ley Constitutiva de las Fuerzas Armadas de 2001, dispone que se entiende por fuero de guerra el conjunto de normas contenidas en la legislación penal militar, a ser aplicadas por los tribunales militares, a los miembros de las Fuerzas Armadas, que estando de alta y en acto de servicio, incurrieren en la comisión de delitos o faltas de naturaleza "estrictamente militar", y que, en caso de conflicto de competencia, en cuanto si es delito común o militar, prevalecerá el fuero común. 
La Constitución de Nicaragua de 1987, en su artículo 93 (reformado en $2005)^{43}$ menciona que el Ejército de ese país es una institución nacional, cuyos miembros deberán recibir capacitación cívica y en materia de derechos humanos, y en donde sobresale que los delitos y faltas estrictamente militares, cometidos por miembros del Ejército, serán conocidos por los tribunales militares establecidos por ley, los delitos y faltas comunes cometidos por los militares serán conocidos por los tribunales comunes. En ningún caso los civiles podrán ser juzgados por tribunales militares. Por otra parte, el Código de Organización, Jurisdicción y Previsión Social Militar de 1994 en su artículo 42 claramente dispone que cuando el delito o falta cometido por los miembros del Ejército fuera común, será conocido por los Tribunales de la Jurisdicción ordinaria y, además, que la iniciativa de la acción penal, de oficio o a petición de parte, corresponderá a la Procuraduría General de Justicia. De igual forma se señala que, cuando el militar sea detenido en flagrante delito o en persecución inmediata del mismo, la acción podrá ejercerse directamente ante los Tribunales de la Jurisdicción Ordinaria. Es decir, este país también se ubica en la tendencia intermedia.

La Constitución Política del Perú de 1993 establece en su artículo 139 que no existe ni puede establecerse jurisdicción alguna independiente, con excepción de la militar y la arbitral, mientras que el artículo 169 señala que tanto las Fuerzas Armadas y la Policía Nacional están subordinadas al poder constitucional. Sin embargo, el artículo 173 dispone que en caso de delito de función, los miembros de las Fuerzas Armadas y de la Policía Nacional están sometidos al fuero respectivo y al Código de Justicia Militar, y que las disposiciones de éste no son aplicables a los civiles, salvo en ciertos delitos.

En ese país se creó una Comisión de la Verdad y Reconciliación Nacional en 2001, para revisar y esclarecer los hechos de violencia terrorista y de violación de los derechos humanos producidos desde mayo de 1980 hasta noviembre de 2000 , en donde se concluyó que los militares con su participación cometieron delitos contra la humanidad, entendidos como tortura, desaparición forzada y genocidio. En todos ellos son los derechos humanos los directamente involucrados y afectados, por lo que no hay un argumento sólido para que se reconozca que los tribunales militares deban ser competentes en estos casos, ya que lo que se afecta aquí no es un bien jurídico castrense y, en el caso de obediencia debida, ésta no es una excusa para evadir responsabilidades. Por

43 La reforma de 2005 consistió en dejar de contemplar a los policías dentro de este artículo 93 constitucional. 
ello, se considera que son los tribunales ordinarios quienes tienen que juzgar, pues uno de los pilares del Estado constitucional es el reconocimiento, respeto y tutela de los derechos fundamentales. ${ }^{44}$

De tal forma, el Código de Justicia Militar Policial de 2006, en su artículo II (romano) referente a la preeminencia de las normas en materia de derechos humanos, prevé que los principios y postulados contenidos en la Constitución relativos a los derechos fundamentales de la persona y en los Tratados Internacionales en materia de Derechos Humanos, ratificados por el Estado Peruano, tienen preeminencia sobre las disposiciones de este Código. Es decir, Perú se ubica en la reciente cuarta tendencia de las doctrinas jurídico-militares, que ha derivado del contexto internacional de los derechos humanos, la cual se ha orientado en el sentido de lograr el constreñimiento de fuero a las materias estrictamente militares.

La Constitución Política de Colombia de 1991, en su artículo 91 señala que en caso de infracción manifiesta de un precepto constitucional en detrimento de alguna persona, el mandato superior no exime de responsabilidad al agente que lo ejecuta, pero los militares en servicio quedan exceptuados de esta disposición, y respecto de ellos la responsabilidad recaerá únicamente en el superior que da la orden. El artículo 116 menciona que administra justicia la Justicia Penal Militar, y que en ningún caso los civiles podrán ser investigados o juzgados por la justicia penal militar (artículo 213).

Por otra parte, el artículo 221 establece que de los delitos cometidos por los miembros de la fuerza pública en servicio activo, y en relación con el mismo servicio, conocerán las cortes marciales o tribunales militares. Complementando lo anterior, el Código Penal Militar, de 17 de agosto de 2010, en su artículo 2o. determina que son delitos relacionados con el servicio aquellos cometidos por los militares en servicio activo dentro o fuera del territorio nacional, cuando los mismos se deriven directamente de la función militar o policial que la Constitución, la ley y los reglamentos les ha asignado. Y en el artículo 3o. menciona que habrá delitos que no se relacionan en ningún caso con el servicio activo, los cuales son los siguientes: tortura, genocidio, desaparición forzada, de lesa humanidad o aquellos que atenten contra el derecho internacional humanitario entendidos en los

44 Cfr. Donayre Montesinos, Christian, "Quién debe juzgar a los miembros de las Fuerzas Armadas en Perú", Iter Criminis. Revista de Ciencias Penales, México, núm. 5, 2006, pp. 22-23, 39-40, 43-45, y 50 y 51. 
términos definidos en convenios y tratados internacionales ratificados por Colombia, ni las conductas que sean abiertamente contrarias a la función constitucional de la Fuerza Pública y que por su sola comisión rompan el nexo funcional del agente con el servicio. Es decir, este país se ubica en la reciente cuarta tendencia de las doctrinas jurídico-militares, y que se ha derivado del contexto internacional de los derechos humanos, la cual se ha orientado en el sentido de lograr el constreñimiento de fuero a las materias estrictamente militares.

\section{LAS RESOLUCIONES DE LA CORTE INTERAMERICANA DE DERECHOS Humanos EN ESTA MATERIA}

El tema del fuero de guerra o militar empezó a tener especial preocupación a partir de mediados de los años noventa, y respecto de América Latina, esto se dio en la Comisión Interamericana de Derechos Humanos y en el Comité de Derechos Humanos, en donde se han analizado y discutido las normas del Derecho Internacional de los Derechos Humanos, y se han observado aquellos derechos que pueden verse afectados cuando los militares que cometen delitos comunes sean procesados y juzgados por militares, supuesto en el cual deben ubicarse, además de los derechos del procesado, los derechos de la víctima del delito. ${ }^{45}$

En este ámbito, lo que reviste de especial gravedad, y sobre todo en la rama penal, es el hecho que están en juego importantes derechos, como son el derecho a la vida y a la libertad personal, y particularmente cuando la víctima es un civil. Así, en caso de que los militares cometan la violación de estos derechos contra civiles y sean los militares quienes procesen y juzguen a los mismos, el primer derecho afectado es el de igualdad ante la ley (respecto de las víctimas del delito, quienes demandan justicia y condiciones de igualdad), señalado en el Pacto Internacional de Derechos Civiles y Políticos de 1966, en su artículo 14.

Por lo anterior, la Comisión Interamericana de Derechos Humanos señaló que la competencia debe ser de tribunales independientes e imparciales y que, en consecuencia, no deben conocer los tribunales militares, puesto que se estaría afectando el principio de igualdad ante la ley. 
Resulta como segundo derecho aquel que tienen ambas partes de acceder a un tribunal independiente e imparcial, el cual presupone la independencia del juez, es decir, que debe existir independencia del Poder Judicial respecto al Poder Ejecutivo. ${ }^{46}$

A partir del análisis de la Jurisprudencia contenciosa (casos de septiembre de 1997 a agosto de 2010) $)^{47}$ de la Corte Interamericana de Derechos Hu-

46 Ibidem, pp. 47, y 49-51.

47 Los casos contenciosos que forman parte de la jurisprudencia de la Corte Interamericana de Derechos Humanos relacionados al tema de fuero militar, son: Caso Loayza Tamayo vs. Perú. Fondo. Sentencia del 17 de septiembre de 1997, Serie C, núm. 33; Caso Loayza Tamayo vs. Perú. Reparaciones y Costas. Sentencia del 27 de noviembre de 1998, Serie C, núm. 42; Caso Castillo Petruzzi y otros vs. Perú. Fondo, Reparaciones y Costas. Sentencia del 30 de mayo de 1999, Serie C, núm. 52; Caso Cesti Hurtado vs. Perú. Fondo. Sentencia del 29 de septiembre de 1999, Serie C, núm. 56; Caso Durand y Ugarte vs. Perú. Fondo. Sentencia del 16 de agosto de 2000, Serie C, núm. 68; Caso Cantoral Benavides vs. Perú. Fondo. Sentencia de 18 de agosto de 2000, Serie C, núm. 69; Caso Bámaca Velásquez vs. Guatemala. Fondo. Sentencia del 25 de noviembre de 2000, Serie C, núm. 70; Caso Las Palmeras vs. Colombia. Fondo. Sentencia del 6 de diciembre de 2001, Serie C, núm. 90; Caso Myrna Mack Chang vs. Guatemala. Fondo, Reparaciones y Costas. Sentencia del 25 de noviembre de 2003, Serie C, núm. 101; Caso 19 Comerciantes vs. Colombia. Fondo, Reparaciones y Costas. Sentencia del 5 de julio de 2004, Serie C, núm. 109; Caso Lori Berenson Mejía vs. Perú. Fondo, Reparaciones y Costas. Sentencia del 25 de noviembre de 2004, Serie C, núm. 119; Caso de la Masacre de Mapiripán vs. Colombia. Fondo, Reparaciones y Costas. Sentencia del 15 de septiembre de 2005, Serie C, núm. 134; Caso Palamara Iribarne vs. Chile. Fondo, Reparaciones y Costas. Sentencia del 22 de noviembre de 2005, Serie C, núm. 135; Caso de la Masacre de Pueblo Bello vs. Colombia. Fondo, Reparaciones y Costas. Sentencia del 31 de enero de 2006, Serie C, núm. 140; Caso Almonacid Arellano y otros vs. Chile. Excepciones Preliminares, Fondo, Reparaciones y Costas. Sentencia del 26 de septiembre de 2006, Serie C, núm. 154; Caso La Cantuta vs. Perú. Fondo, Reparaciones y Costas. Sentencia del 29 de noviembre de 2006, Serie C, núm. 162; Caso de la Masacre de la Rochela vs. Colombia. Fondo, Reparaciones y Costas. Sentencia del 11 de de mayo de 2007, Serie C, núm. 163; Caso Escué Zapata vs. Colombia. Fondo, Reparaciones y Costas. Sentencia del 4 de julio de 2007, Serie C, núm. 165; Caso Zambrano Vélez y otros vs. Ecuador. Fondo, Reparaciones y Costas. Sentencia del 4 de julio de 2007, Serie C, núm. 166; Caso Tiu Tojín vs. Guatemala. Fondo, Reparaciones y Costas. Sentencia del 26 de noviembre de 2008, Serie C, núm. 190; Caso Usón Ramírez vs. Venezuela. Excepción Preliminar, Fondo, Reparaciones y Costas. Sentencia del 20 de noviembre de 2009, Serie C, núm. 207; Caso Radilla Pacheco vs. México. Excepciones Preliminares, Fondo, Reparaciones y Costas. Sentencia del 23 de Noviembre de 2009, Serie C, núm. 209; Caso Fernández Ortega y otros. vs. México. Excepción Preliminar, Fondo, Reparaciones y Costas. Sentencia del 30 de agosto de 2010, Serie C, núm. 215, y Caso Rosendo Cantú y otra vs. México. Excepción Preliminar, Fondo, Reparaciones y Costas. Sentencia del 31 de agosto de 2010 Serie $\mathrm{C}$, núm. 216. 
manos, ésta reiteradamente ha establecido que la jurisdicción penal militar en los Estados democráticos, en tiempos de paz, ha tendido a reducirse e incluso, a desaparecer, por lo cual, considera que en caso de que un Estado la conserve, su utilización debe ser mínima, según sea estrictamente necesario, y debe encontrarse inspirada en los principios y garantías que rigen el derecho penal moderno. ${ }^{48}$

Pone especial énfasis al señalar que en un Estado democrático de derecho, la jurisdicción penal militar ha de tener un alcance restrictivo y excepcional y estar encaminada a la protección de intereses jurídicos especiales, vinculados a las funciones propias de las fuerzas militares. Por ello, ha señalado que en el fuero militar sólo se debe juzgar a militares activos por la comisión de delitos o faltas que por su propia naturaleza atenten contra bienes jurídicos propios del orden militar. ${ }^{49}$

Del mismo modo, dicha Corte ha establecido que, tomando en cuenta la naturaleza del crimen y el bien jurídico lesionado, la jurisdicción penal militar no es el fuero competente para investigar y, en su caso, juzgar y sancionar a los autores de violaciones de derechos humanos, sino que el procesamiento de los responsables debe corresponder siempre a la justicia ordinaria. Es por ello que la Corte, en múltiples ocasiones, ha indicado que si a justicia militar asume competencia sobre un asunto que debe conocer la justicia ordinaria, entonces se ve afectado el derecho al juez natural y, a fortiori, el debido proceso, el cual, a su vez, se encuentra íntimamente ligado al propio derecho de acceso a la justicia. En resumen, el juez encargado del conocimiento de una causa debe ser competente, además de independiente e imparcial. ${ }^{50}$

Para que se respete el derecho al juez natural, el Tribunal ha señalado que no basta con que la ley establezca previamente cuál será el tribunal que atenderá una causa y que le otorgue competencia a éste. Dicha ley, al otorgar competencias en el fuero militar y al determinar las normas penales militares aplicables en dicho fuero, debe establecer claramente y sin ambigüedad lo siguiente: ${ }^{51}$ a) quiénes son militares, únicos sujetos

48 Cfr. Caso Radilla Pacheco vs. México. Excepciones Preliminares, Fondo, Reparaciones y Costas. Sentencia del 23 de noviembre de 2009, Serie C, núm. 209, párrafo 272.

49 Idem.

50 Ibidem, párrafo 273.

51 Cfr. Caso Usón Ramírez vs. Venezuela. Excepción Preliminar, Fondo, Reparaciones y Costas. Sentencia del 20 de noviembre de 2009, Serie C, núm. 207, párrafo 110. 
activos de los delitos militares; b) cuáles son las conductas delictivas típicas en el especial ámbito militar; c) la conducta ilícita a través de la descripción de la lesión o puesta en peligro de bienes jurídicos militares gravemente atacados, que justifique el ejercicio del poder punitivo militar, y d) la correspondiente sanción, teniendo en cuenta el principio de proporcionalidad.

Las autoridades que ejercen la jurisdicción penal militar, al aplicar las normas penales militares e imputar a un militar de un delito, también deben regirse por el principio de legalidad y, entre otras, constatar la existencia de todos los elementos constitutivos del tipo penal militar, así como la existencia o inexistencia de causales de exclusión del delito. ${ }^{52}$

La Corte destaca que cuando los tribunales militares conocen de actos constitutivos de violaciones a derechos humanos en contra de civiles ejercen jurisdicción no solamente respecto del imputado, el cual necesariamente debe ser una persona con estatus de militar en situación de actividad, sino también sobre la víctima civil, quien tiene derecho a participar en el proceso penal no sólo para efectos de la respectiva reparación del daño, sino también para hacer efectivos sus derechos a la verdad y a la justicia. En tal sentido, las víctimas de violaciones a derechos humanos y sus familiares tienen derecho a que tales violaciones sean conocidas y resueltas por un tribunal competente, de conformidad con el debido proceso y el acceso a la justicia. Así, la importancia del sujeto pasivo trasciende la esfera del ámbito militar, ya que se encuentran involucrados bienes jurídicos propios del régimen ordinario. ${ }^{53}$

La Corte observó, independientemente de la incompetencia per se de los tribunales militares para juzgar violaciones de derechos humanos, serias irregularidades cometidas deliberada y sistemáticamente en algunos casos (por ejemplo, caso La Cantuta vs. Perú. Fondo, Reparaciones y Costas. Sentencia del 29 de noviembre de 2006, Serie C, núm. 162), ya que éstas fueron llevadas a cabo por los diferentes poderes del Estado para apoyar la intervención de la justicia militar y definir finalmente su competencia; dichas prácticas revelaron una política de entorpecimiento de las investigaciones en la justicia ordinaria con la clara intención de encubrir a los responsables,

52 Cfr. Caso Palamara Iribarne vs. Chile. Fondo, Reparaciones y Costas. Sentencia del 22 de noviembre de 2005, Serie C, núm. 135, párrafo 126.

53 Cfr. Caso Radilla Pacheco vs. México, op. cit., párrafo 275. 
por lo que concluyó que esta política oficial de encubrimiento y obstrucción pone de relieve la existencia de un contexto general de impunidad.

Por ello afirma que la jurisdicción militar no ofrece las garantías de independencia e imparcialidad necesarias para el juzgamiento de casos que involucran a miembros de las Fuerzas Armadas. Así, características como la subordinación al Poder Ejecutivo, la subordinación jerárquica y la situación de actividad de los magistrados militares que ejercen la función jurisdiccional, impiden que el fuero militar sea considerado como un verdadero sistema judicial. ${ }^{54}$

Respecto de la necesidad de que un juez o tribunal militar cumpla con las condiciones de independencia e imparcialidad, es imprescindible recordar lo establecido por esta Corte Interamericana de Derechos Humanos en el sentido de que es necesario que se garanticen las referidas condiciones en un Estado de derecho, ya que la independencia de cualquier juez supone que se cuente con un adecuado proceso de nombramiento, con una duración establecida en el cargo, garantías de inamovilidad y con una garantía contra presiones externas. En el mismo sentido, se expresan los Principios Básicos de Naciones Unidas relativos a la Independencia de la Judicatura. ${ }^{55}$

Dicha Corte estimó conveniente subrayar que el proceso penal es uno solo a través de sus diversas etapas, tanto la correspondiente a la primera instancia como las relativas a instancias ulteriores. En consecuencia, el concepto del juez natural y el principio del debido proceso legal rigen a lo largo de esas etapas y se proyectan sobre las diversas instancias procesales, ${ }^{56}$ y considera que la sola posibilidad de que las decisiones emanadas de tribunales militares puedan ser "revisadas" por las autoridades federales no satisface el principio del juez natural, ya que desde la primera instancia el juez debe ser competente. ${ }^{57}$

54 Cfr. Caso La Cantuta vs. Perú. Fondo, Reparaciones y Costas. Sentencia del 29 de noviembre de 2006, Serie C, núm. 162, párrafo 130, inciso g.

55 Cfr. Caso Palamara Iribarne vs. Chile, op. cit., párrafo 156. Los Principios Básicos relativos a la Independencia de la Judicatura pueden ser consultados en la página de Internet de la Oficina del Alto Comisionado de las Naciones Unidas para los Derechos Humanos, en línea en http://www2.ohchr.org/spanish/law/judicatura.htm, consultado el 27 de octubre de 2010.

56 Cfr. Caso Castillo Petruzzi y otros vs. Perú. Fondo, Reparaciones y Costas. Sentencia del 30 de mayo de 1999, Serie C, núm. 52, párrafo 161.

57 Cfr. Caso Radilla Pacheco vs. México, op. cit., párrafo 281. 
Por lo anterior, el principio ne bis in idem, aun cuando es un derecho humano reconocido en el artículo 8.4 de la Convención Americana sobre Derechos Humanos de 1969 o Pacto de San José, no es un derecho absoluto y, por tanto, no resulta aplicable cuando se dé uno o varios de los siguientes supuestos: ${ }^{58}$

a) la actuación del tribunal que conoció el caso y decidió sobreseer o absolver al responsable de una violación a los derechos humanos o al derecho internacional obedeció al propósito de sustraer al acusado de su responsabilidad penal;

b) el procedimiento no fue instruido independiente o imparcialmente de conformidad con las debidas garantías procesales, o

c) no hubo la intención real de someter al responsable a la acción de la justicia. Una sentencia pronunciada en las circunstancias indicadas produce una cosa juzgada "aparente" o "fraudulenta".

Por otro lado, la Corte considera que si aparecen nuevos hechos o pruebas que puedan permitir la determinación de los responsables de violaciones a los derechos humanos, y más aún, de los responsables de crímenes de lesa humanidad, pueden ser reabiertas las investigaciones, incluso si existe una sentencia absolutoria en calidad de cosa juzgada, puesto que las exigencias de la justicia, los derechos de las víctimas y la letra y espíritu de la Convención Americana desplaza la protección del ne bis in idem. ${ }^{59}$

La Corte Interamericana en reiteradas ocasiones ha señalado que el artículo 25, con relación al artículo 1.1 de la Convención Americana, obliga al Estado a garantizar a toda persona el acceso a la administración de justicia $\mathrm{y}$, en particular, a un recurso rápido y sencillo para lograr, entre otros resultados, que los responsables de las violaciones de los derechos humanos sean juzgados y para obtener una reparación por el daño sufrido. Como ha dicho textualmente la Corte, el artículo 25 "constituye uno de los pilares básicos, no sólo de la Convención Americana, sino del propio Estado de derecho en una sociedad democrática en el sentido de la Convención". Dicho artículo guarda relación directa con el artículo 8.1

58 Cfr. Caso Almonacid Arellano y otros vs. Chile. Excepciones Preliminares, Fondo, Reparaciones y Costas. Sentencia del 26 de septiembre de 2006, Serie C, núm. 154, párrafo 154.

59 Idem. 
de la Convención Americana que consagra el derecho de toda persona a ser oída con las debidas garantías y dentro de un plazo razonable, por un juez o tribunal independiente e imparcial, para la determinación de sus derechos de cualquier naturaleza. ${ }^{60}$

Por consiguiente, el Estado tiene el deber de investigar las violaciones de los derechos humanos, procesar a los responsables y evitar la impunidad. ${ }^{61}$

De igual manera, la Corte Interamericana ha definido la impunidad como "la falta en su conjunto de investigación, persecución, captura, enjuiciamiento y condena de los responsables de las violaciones de los derechos protegidos por la Convención Americana" ${ }^{62}$ y ha señalado que es el Estado quien tiene la obligación de combatir tal situación por todos los medios legales disponibles, ya que la impunidad propicia la repetición crónica de las violaciones de derechos humanos y la total indefensión de las víctimas y sus familiares. ${ }^{63}$

Esta garantía del debido proceso debe analizarse de acuerdo al objeto y fin de la Convención Americana, cual es la eficaz protección de la persona humana. Por estas razones, y por la naturaleza del crimen y el bien jurídico lesionado, la jurisdicción penal militar no es el fuero competente para investigar y, en su caso, juzgar y sancionar a los autores de violaciones de derechos humanos. ${ }^{64}$

En este sentido, el Tribunal ha establecido que para que el Estado cumpla lo dispuesto en el artículo 25 de la Convención Americana no basta con que los recursos existan formalmente, sino que es preciso que tengan efectividad en los términos de aquel precepto. La Corte ha reiterado que dicha obligación implica que el recurso sea idóneo para combatir la violación y que sea efectiva su aplicación por la autoridad competente. ${ }^{65}$

En la Convención Americana se prevé, en su artículo 2o., la obligación general de cada Estado Parte de adecuar su derecho interno a las disposiciones de la misma, para garantizar los derechos en ella reconocidos, lo cual

${ }^{60}$ Cfr. Caso Loayza Tamayo vs. Perú. Reparaciones y Costas. Sentencia del 27 de noviembre de 1998. Serie C, núm. 42, párrafo 169.

${ }^{61}$ Ibidem, párrafo 170.

62 Caso 19 Comerciantes vs. Colombia. Fondo, Reparaciones y Costas. Sentencia del 5 de julio de 2004, Serie C, núm. 109, párrafo 175.

${ }^{63}$ Cfr. Caso Loayza Tamayo vs. Perú. Reparaciones y Costas, op. cit., párrafo 170.

${ }^{64}$ Cfr. Caso de la Masacre de La Rochela vs. Colombia. Fondo, Reparaciones y Costas. Sentencia del 11 de mayo de 2007, Serie C, núm. 163, párrafo 200.

65 Cfr. Caso Radilla Pacheco vs. México, op. cit., párrafo 296. 
implica que las medidas de derecho interno han de ser efectivas (principio de effet utile). El argumento anterior ha sido sostenido en diversas oportunidades por la Corte, en el entendido de que en el derecho de gentes, una norma consuetudinaria prescribe que un Estado que ha celebrado un convenio internacional, debe introducir en su derecho interno las modificaciones necesarias para asegurar la ejecución de las obligaciones asumidas. ${ }^{66}$

Para la Corte Interamericana no sólo la supresión o expedición de las normas en el derecho interno garantizan los derechos contenidos en la Convención Americana, de conformidad a la obligación comprendida en el artículo 20. de dicho instrumento, en virtud de que se requiere, además, el desarrollo de prácticas estatales conducentes a la observancia efectiva de los derechos y libertades consagrados en la misma. En consecuencia, no puede aducirse que la existencia de una norma garantice, por sí misma, una aplicación adecuada. Es necesario que la aplicación de las normas o su interpretación, en tanto prácticas jurisdiccionales y manifestación del orden público estatal, se encuentren ajustadas al mismo fin que persigue el artículo 20. de la Convención. ${ }^{67}$

En torno a las prácticas judiciales, la Corte Interamericana ha establecido en su jurisprudencia que es consciente de que los jueces y tribunales internos están sujetos al imperio de la ley y, por ello, están obligados a aplicar las disposiciones vigentes en el ordenamiento jurídico. Pero cuando un Estado ha ratificado un tratado internacional como es la Convención Americana sobre Derechos Humanos, sus jueces, como parte del aparato estatal, también están sometidos a ella, lo que les obliga a velar porque los efectos de las disposiciones de la Convención no se vean mermados por la aplicación de leyes contrarias a su objeto y fin, que desde un inicio carecen de efectos jurídicos. ${ }^{68}$

En otras palabras, el Poder Judicial debe ejercer un "control de convencionalidad" ex officio entre las normas internas y la Convención Americana, evidentemente en el marco de sus respectivas competencias y de las regulaciones procesales correspondientes. En esta tarea, el Poder Judicial debe tener en cuenta no solamente el tratado internacional (Tratado, Convenio o Pacto), sino también la interpretación que del mismo ha hecho la Corte Interamericana, intérprete última de la Convención Americana. ${ }^{69}$

${ }^{66}$ Ibidem, párrafo 288.

67 Ibidem, párrafo 338.

${ }^{68}$ Cfr. Caso Almonacid Arellano y otros vs. Chile, op. cit., párrafo 124.

69 Cfr. Caso Radilla Pacheco vs. México, op. cit., párrafo 339. 
En algunas legislaciones, en las que ha avanzado mucho más la tendencia restrictiva de la jurisdicción militar, se agrega una exigencia sobre la circunstancia requerida para que actúe aquella jurisdicción: tiempo o situación de guerra. El hecho de que sólo en esta circunstancia opere la justicia castrense refuerza el carácter funcional del Derecho militar y de la jurisdicción respectiva y constituye, evidentemente, un dato elocuente sobre su carácter esencialmente excepcional. ${ }^{70}$

El Estado deberá adoptar medidas tendentes a formar y capacitar a los fiscales y jueces, incluidos aquéllos del fuero penal militar, en cuanto a los estándares internacionales en materia de protección judicial de derechos humanos. Para ello, el Estado deberá implementar, de igual manera, en un plazo razonable, programas permanentes de educación en derechos humanos dirigidos a aquellos funcionarios. ${ }^{71}$

Finalmente, la Corte considera que las actividades de las fuerzas militares y de la policía, y de los demás organismos de seguridad, deben sujetarse rigurosamente a las normas del orden constitucional democrático y a los tratados internacionales de derechos humanos y de Derecho Internacional Humanitario. Esto es especialmente válido respecto a los organismos y las actividades de inteligencia. Los referidos organismos deben, inter alia: a) ser respetuosos, en todo momento, de los derechos fundamentales de la personas, y b) estar sujetos al control de las autoridades civiles, incluyendo no sólo las de la rama ejecutiva, sino también las de los otros poderes públicos, en lo pertinente. Las medidas tendentes a controlar las labores de inteligencia deben ser especialmente rigurosas, puesto que, dadas las condiciones de reserva bajo las que se realizan esas actividades, pueden derivar hacia la comisión de violaciones de los derechos humanos y de ilícitos penales. ${ }^{72}$

70 Voto razonado concurrente del Juez Sergio García Ramírez a la sentencia sobre el caso Palamara Iribarne vs. Chile, op. cit., párrafo 12.2

71 Cfr. Caso La Cantuta vs. Perú, párrafo 241.

72 Cfr. Caso Myrna Mack Chang vs. Guatemala. Fondo, Reparaciones y Costas. Sentencia del 25 de noviembre de 2003, Serie C, núm. 101, párrafo 284. 


\section{EL CASO PARTICULAR DE MÉXICO: EL ARTÍCULO 13 CONSTITUCIONAL Y LAS TESIS DE LA SCJN}

En sus inicios ${ }^{73}$, el fuero miliar (así como el eclesiástico) se estableció en la Constitución de Cádiz de 1812, y las siguientes Constituciones (1824 y 1836) fueron repitiendo la misma idea, ésta consistía en que aquél abarcaba distintas materias y los no miembros se tenían que sujetar a él, siempre y cuando estuviese involucrado algún militar. Es con la Constitución de 1857 cuando se limita sólo a la materia penal. ${ }^{74}$ Posteriormente, el Constituyente de 1917 excluyó a los paisanos (connacional o extranjero) pero, a pesar de que hubo escepticismo hacia el fuero militar, fue cuestionado por los constituyentes Francisco J. Múgica, Esteban Vaca e Hilario Medina (dos militares y un abogado), quienes incluso propusieron restringirlo, eliminarlo y transferirlo al Poder Judicial; la existencia de éste fue aprobada por dos terceras partes del Congreso Constituyente (122 votos a favor y 61 en contra). ${ }^{75}$

En la actualidad, la Constitución Política de los Estados Unidos Mexicanos de 1917 (vigente) hace referencia a las fuerzas armadas, con distintos términos, en los artículos 13, 29, 55 (y 58 indirectamente), 73, 76, 78, 82, 89 y 129 , con relación a los artículos 5o., 10, 16, 22, 31, 32, 35 y 123;76 además, existe abundante jurisprudencia de la SCJN en esta materia y el Código de Justicia Militar. Este último considerado como una norma que no ha tenido actualizaciones de fondo y siendo que data de 1933, a juicio de varios autores, tiene términos obsoletos como la Secretaría de Guerra y Marina. ${ }^{77}$

Particularmente, los artículos 13 y 21 constitucional dan sustento al Ministerio Público y, en específico, al Ministerio Público Militar representado por un órgano del fuero de guerra denominado como Procuraduría General

73 Si se desea ver la historia del fuero de guerra en México, consúltese Calderón Serrano, Ricardo, op. cit., pp. 749-755.

${ }^{74}$ Cfr. Romero Apis, José Elías, "Génesis y vigencia del Artículo 13 en el constituyente de 1917", Revista del Ejército y Fuerza Aérea Mexicanos. El fuero de guerra, su constitucionalidad, México, julio de 1999, p. 8.

75 Cfr. González Oropeza, Manuel, op. cit., p. 43.

76 Si se quiere profundizar en su contenido, consúltese Saucedo López, Antonio, Los tribunales militares en México, Trillas, México, 2002, pp. 43-46.

77 Cfr. Saucedo López, Antonio, Teoría jurídica del Ejército y sus lineamientos constitucionales, México, UNAM, Instituto de Investigaciones Jurídicas de la UNAM, 2002, p. 63. 
de Justicia Militar, dependiente del Poder Ejecutivo. ${ }^{78}$ Por otro lado, pero en estrecha vinculación con lo anterior, son partes en el proceso militar de acuerdo con el artículo 439 del Código de Justicia Militar el Ministerio Público, el procesado y sus defensores. ${ }^{79}$

Como antecedentes después del texto constitucional y de la publicación del Código de Justicia Militar tenemos que en 1944, por medio de una reforma, se facultó al presidente de la República para disponer de las Fuerzas Armadas: Ejército, Marina de Guerra y Fuerza Aérea, sin más limitación, y teniendo por objeto la seguridad interior y la defensa exterior de la Federación ${ }^{80}$. Así, en 1968, el Presidente de la República en turno puso en movimiento al Ejército provocando una grave crisis con relación a un movimiento estudiantil de esos años. ${ }^{81}$

Durante 1988 y hasta 1994, el presidente correspondiente a ese periodo recurrió a las fuerzas armadas para las labores de combate al narcotráfico $\mathrm{y}$, circunstancialmente, frente a elecciones estatales competidas, como guardianes electorales. Entre 1994 y 1995, las fuerzas armadas mostraron poco a poco su descontento por el escaso reconocimiento a sus funciones institucionales en el sistema político y en la estructura del Estado. Así, el presidente en turno reconoció públicamente la importancia institucional de la milicia. ${ }^{82}$

Es pertinente señalar que, a lo largo de varios años, en México las fuerzas armadas no son una élite social; son una institución que recibe e integra libremente a personas de todas las clases sociales y, para millones de personas que han enfrentado desastres naturales de gran magnitud, la presencia de los militares no es un símbolo de represión. Muy por el contrario, la mayoría de la sociedad reconoce sus actos de entrega y valentía en momentos de crisis humanitarias, de solidaridad y de generosidad.

Dentro de este sistema político, basado en la práctica de la libertad y el respecto a la dignidad de la persona humana, tanto el cuerpo militar como policial deben depender de la autoridad civil y actuar bajo un orden jurídico,

78 Cfr. Calnacasco Santamaría, Carlos, "El ministerio público como institución del fuero de guerra", Revista Mexicana de Procuración de Justicia, Procuraduría General de Justicia del Distrito Federal, México, vol. 1, núm. 1, febrero de 1996, p. 41.

79 Cfr. Calnacasco Santamaría, Carlos, op. cit., p. 45.

80 Cfr. Fernández Segado Francisco, op. cit., pp. 233 y 244.

81 Cfr. González Oropeza, Manuel, op. cit., p. 46.

82 Cfr. Senado de la República, Documentos históricos constitucionales de las Fuerzas Armadas Mexicanas, México, 1965-1966, pp. 167 a 171, 176, 177, 183 y 185. 
cuyas bases se asientan en la Constitución; por ello, se ha de evitar recurrir a la arbitrariedad, toda vez que cualquier violación de las normas establecidas en este sentido, debe sancionarse. Basta que se dé la impunidad para que surjan las violaciones sistemáticas.

Particularmente, el artículo 13 constitucional hace referencia al Ejército y no a las Fuerzas Armadas, las cuales se integran por el Ejército, Marina de Guerra y Fuerza Aérea, ya que éstas dos últimas, en la época del constituyente, estaban en una existencia incipiente, por lo que debe darse la reforma a este artículo para establecer: "personas pertenecientes a las Fuerzas Armadas" ${ }^{83}$ Asimismo, por su redacción, a partir de 1944 e incluso desde antes, se consideró que este artículo adolece de técnica legislativa y que tiene pleonasmo, es por eso que dichas deficiencias la tratan de corregir con el contenido del artículo 57 del Código de Justicia Militar ${ }^{84}$ señalando el artículo 58 señala qué legislación se aplicará dependiendo del lugar donde se cometió el delito. ${ }^{85}$

El artículo 13 constitucional contempla el fuero militar tanto por la persona como por la materia. Durante varios años no recibió cuestionamiento alguno (en los años cuarenta es cuando se escribió más sobre éste) por los autores (al menos no por muchos); en algunos casos simplemente se explicaba, en otros se hacía referencia a que existía impunidad por encontrarse favorecidos los militares, y algunos más han considerado que los militares tienen desventajas con relación a cualquier ciudadano. ${ }^{86}$ Incluso, hoy en día, el fuero de guerra, militar o castrense constituye, entonces, una garantía de los militares, es decir, de aquellos servidores públicos que tienen grado en las Fuerzas Armadas, así como un régimen jurídico especializado en delitos y faltas contra la disciplina militar. ${ }^{87}$

Veamos que este artículo 13 señala textualmente lo siguiente:

83 Cfr. Saucedo López, Antonio, op. cit., p. 62.

84 Cfr. Calderón Serrano, Ricardo, op. cit., p. 751, y Cabrera Vázquez, Juan, "Fundamentación jurídica del fuero de guerra", en Boletín Jurídico Militar, Secretaría de la Defensa Nacional, tomo X, números 1 y 2, México, enero-febrero de 1944, pp. 65-71.

${ }^{85}$ Cfr. Fromow García, Mario Guillermo, "El fuero militar no es un privilegio", Iter Criminis. Revista de Ciencias Penales, México, número 12, 2005, p. 179.

${ }^{86}$ Cfr. Espinosa, Alejandro Carlos, Derecho militar mexicano, México, Porrúa, 2005, pp. 15-28.

87 Cfr. González Licea, Genaro, op. cit., p. 45. 
Nadie puede ser juzgado por leyes privativas ni por tribunales especiales. Ninguna persona o corporación puede tener fuero, ni gozar más emolumentos que los que sean compensación de servicios públicos y estén fijados por la ley. Subsiste el fuero de guerra para los delitos y faltas contra la disciplina militar; pero los tribunales militares en ningún caso y por ningún motivo podrán extender su jurisdicción sobre personas que no pertenezcan al Ejército. Cuando en un delito o falta del orden militar estuviese complicado un paisano, conocerá del caso la autoridad civil que corresponda.

Es en este precepto donde se determina lo relativo al denominado fuero militar y, básicamente, encontramos tres supuestos distintos, los cuales a continuación se analizan:

1. Subsiste el fuero de guerra para los delitos y faltas contra la disciplina militar;

2. Los tribunales militares en ningún caso y por ningún motivo podrán extender su jurisdicción sobre personas que no pertenezcan al Ejército, y

3. Cuando en un delito o falta del orden militar estuviese complicado un paisano, conocerá del caso la autoridad civil que corresponda.

En cuanto al primer supuesto, subsiste el fuero de guerra para los delitos y faltas contra la disciplina militar, en la propia Constitución se establece un fuero particular, el fuero militar destinado a conocer de los delitos y las faltas en contra de la disciplina militar, cometidos por los elementos de las fuerzas armadas. Dichos delitos y faltas en contra de la disciplina militar se encuentran regulados en el Código de Justicia Militar, en los términos siguientes:

Artículo 57. Son delitos contra la disciplina militar:

I. Los especificados en el Libro Segundo de este Código;

II. Los del orden común o federal cuando en su comisión haya concurrido cualquiera de las circunstancias que en seguida se expresa:

a) Que fueren cometidos por militares en los momentos de estar en servicio o con motivos de actos del mismo;

b) a e)... 
En el primer caso, los delitos especificados en el Libro Segundo del Código de Justicia Militar, son propios de la actividad militar (por ejemplo, sedición, rebelión, deserción e insumisión, insubordinación, desobediencia, asonada, etcétera) y se advierte que están contemplados a efecto de la conservación de la disciplina de las fuerzas armadas.

En el campo de la jurisprudencia se observa que "deben ser militares los que juzguen en el caso de delitos contra la disciplina militar, o bien que impongan sanciones para el caso de las faltas, pues la vida civil se aparta plenamente de ese espíritu de sacrificio que sólo entienden los que han vivido en el sistema castrense" ${ }^{88}$ Se instituye el fuero para los delitos y faltas contra la disciplina militar, que vaya en forma paralela al fuero federal y al fuero común, para que quienes integren los aspectos jurisdiccionales, o disciplinarios, sean órganos ex professo organizados para llevar a cabo la incoación y la substanciación de procedimientos. Así, el fuero militar atiende a los delitos y faltas contra la disciplina, como lo señala el artículo 13 de la Constitución, que aun cuando estas últimas vulneran la disciplina de las fuerzas armadas, su efecto es considerado, por algunos autores, como no grave y puede ser encausado al ámbito restitutivo por medio de una sanción de carácter administrativo-militar.

Por lo anterior, la jurisdicción militar es la potestad que tienen los tribunales militares para conocer de los procesos castrenses, resolverlos por medio de una sentencia y ejecutar la misma en los términos de ley. Mientras que competencia es el conocimiento de dichos procesos, que atienden a los asuntos exclusivos del fuero militar, excluyendo a los demás que se cometan por personas ajenas a las fuerzas militares y que sean competencia de otros fueros subsistentes dentro del sistema perteneciente al Poder Judicial Federal o local, en su caso. ${ }^{89}$

En este contexto, en "el Ejército un superior no puede ser juzgado por un elemento de menor jerarquía; siempre debe ser cuestionado, por uno de igual o mayor rango. Priva el principio de que los pares deben juzgar a sus pares en su doble vertiente: calidad de militar e igualdad de jerarquía". ${ }^{90}$ Existen en todo el país seis juzgados militares, que se ubican principalmente en el Distrito Federal.

88 Saucedo López, Antonio, op. cit., p. 59.

${ }^{89}$ Cfr. Ibidem, pp. 59, 61 y 62.

90 Fromow García, Mario Guillermo, op. cit., p. 175. 
Por lo que se refiere a la fracción II, inciso a), del artículo 57 del Código de Justicia Militar se trata de los delitos del fuero federal o común, cuando éstos son cometidos por el personal militar al momento de estar en servicio o con motivo de los actos del propio servicio. En este caso, el propio Código de Justicia Militar establece que serán los tribunales militares los que conozcan de estos casos y, para tal efecto, aplicarán el código penal que estuviere vigente en el lugar de los hechos al cometerse el delito, o bien, el Código Penal Federal, si se tratase de delitos de este orden.

A ese respecto, no hay lugar a dudas que si un elemento militar comete un delito común o federal en el ejercicio de sus funciones, o con motivo de éstas (ejemplo, homicidio, violación, robo, daño en propiedad ajena, delitos contra la salud, etcétera) debe ser juzgado por los tribunales militares. Asimismo, se considera que las penas en la jurisdicción ordinaria buscan la readaptación social, mientras que el fuero militar se busca un castigo severo en donde prevalezca el principio militar "el temor mantiene quietas a las turbas". ${ }^{91}$ Para los militares, un "Ejército sin disciplina sería una chusma armada y, por ende, una amenaza y un peligro para la sociedad, de ahí la severidad de las leyes". ${ }^{92}$

El segundo supuesto del artículo 13 de la Constitución en cuanto al fuero de guerra, en el sentido de que los tribunales militares en ningún caso y por ningún motivo podrán extender su jurisdicción sobre personas que no pertenezcan al Ejército, no ofrece ninguna dificultad interpretativa; esto es, se establece una prohibición absoluta y sin excepciones para que los tribunales militares puedan juzgar a alguna persona que no pertenezca al Ejército.

Se define claramente en el texto constitucional la existencia del fuero militar, pero limitado éste a juzgar determinados actos de elementos pertenecientes a las fuerzas armadas que podrá extender su jurisdicción a civiles. En este sentido, se advierte que elementos de las fuerzas armadas pueden ser juzgados por tribunales civiles cuando los delitos no sean cometidos en el ejercicio de sus funciones o con motivo de éstas (ejemplo, cuando los militares están de francos), pero bajo ninguna circunstancia, un tribunal militar podrá conocer de los delitos cometidos por civiles.

Es quizá el tercer supuesto del artículo 13 de la Constitución el que pudiera generar mayores confusiones; el texto establece que cuando en un delito o falta del orden militar estuviese complicado un paisano, conocerá

91 Ibidem, p. 176.

92 Ibidem, p. 183. 
del caso la autoridad civil que corresponda. Esta última parte de dicho artículo constitucional pretende definir claramente qué pasa cuando se da la comisión de un delito del orden militar, esto es, el cometido por elementos del Ejército en ejercicio de sus funciones o con motivo de éstas y en el que estuviera complicado (implicado) un paisano (un civil, alguien que no pertenece a las fuerzas armadas). En este caso, en primer lugar, se reafirma lo señalado en el segundo supuesto del fuero militar, en el sentido de que ningún civil puede ser juzgado por los tribunales militares, y en segundo lugar, el texto es claro al manifestar que cuando estuviere complicado un paisano conocerá del caso la autoridad civil que corresponda.

Aquí la pregunta que puede surgir es ¿en estos casos quién debe juzgar a los militares? Al respecto, la SCJN ha emitido una tesis aislada que define y da respuesta concreta a esta pregunta: ${ }^{93}$

MiLitARES. Delitos COMETIDOS POR LOS, EN LOS QUE INTERVIENEN CIVILES. COMPETENCIA. El artículo 13 de la Constitución General de la República, debe interpretarse en forma correcta, jurídicamente, en el sentido de que cuando intervengan militares y civiles en un delito, el militar debe ser juzgado por las autoridades militares, y el segundo por las del orden común o federal que corresponda según el caso, pues interpretarlo de otra manera equivale a suprimir el fuero de guerra, cuando intervengan paisanos, dado que ese fuero se estableció para que los militares sean juzgados siempre cuando cometan un delito contra la disciplina militar, por los tribunales militares, y sujetarlos a una autoridad civil sería contrario a la interpretación correcta del artículo constitucional citado.

Esta interpretación de la Suprema Corte de Justicia de la Nación deja completamente claro que cuando en un delito que pueda configurarse como del fuero militar, participen también elementos ajenos al Ejército, éstos deben ser juzgados por tribunales civiles, mientras que los elementos militares por los tribunales castrenses; el elemento fundamental para determinar qué fuero debe juzgar a los militares será si las conductas delictivas se configuran en términos de lo dispuesto en el artículo 57 del Código de Justicia Militar.

Asimismo, la Suprema Corte de Justicia de la Nación, en tesis aisladas, ha definido quién debe juzgar a los militares cuando éstos cometen un delito en perjuicio de los particulares:

93 Semanario Judicial de la Federación, Sexta Época, instancia: Pleno, primera parte L, p. 22, registro 258142 . 
Militares. Delito COMETido en PerJuicio de Particulares. CompeTENCIA. El artículo 57, fracción II, inciso a), del Código de Justicia Militar, previene que son delitos contra la disciplina militar los del orden común o federal, cuando fueren cometidos por militares en los momentos de estar en servicio o con motivo del mismo. Por tanto, si consta que los inculpados se encontraban desempeñando servicio de armas cuando cometieron los hechos delictuosos por los que fueron acusados (lesiones, daño en propiedad ajena y abuso de autoridad), y por los que se les motivó prisión, aunque esos delitos son del orden común, como fueron cometidos por militares en los momentos en que estaban en servicio, quedan comprendidos en la fracción II, inciso a), del artículo 57 ya citado del código castrense, y por lo mismo deben considerarse como delitos contra la disciplina militar, que el citado código clasifica como violencia contra las personas, a que se refiere el artículo 330 del mismo ordenamiento, que impone pena al que hiciere innecesariamente uso de las armas contra cualquier persona, o que sin autorización ejerciere otro acto injustificado de violencia contra algún individuo. Ahora bien, el artículo 13 de la Constitución General de la República, dejó subsistente el fuero de guerra para los delitos y faltas contra la disciplina militar, por lo que estos delitos deben ser juzgados y castigados por los tribunales militares. ${ }^{94}$

MILITARES, DELITOS COMETIDOS EN PERJUICIO DE PARTICULARES. Competencia. Si aparece probado que el procesado tenía carácter militar, y se encontraba en servicio el día en que causó la muerte de un civil, lo que también aparece de su declaración, el delito por el que se le procesa es contra la disciplina militar, de acuerdo con lo dispuesto en el artículo 57, fracción II, inciso a), del Código de Justicia Militar, que dice: son delitos contra la disciplina militar los del orden común o federal que fueren cometidos por militares en los momentos de estar en servicio o con motivo de actos del mismo, y por lo mismo corresponde conocer del proceso que le sigue al inculpado, a las autoridades militares. ${ }^{95}$

Incluso, por su importancia para el tema, se cita una tesis aislada del Segundo Tribunal Colegiado en Materia Penal del Primer Circuito, que no sólo ratifica las interpretaciones anteriores, sino las hace extensivas a otras actividades militares:

94 Semanario Judicial de la Federación, Sexta Época, instancia: Pleno, primera parte XLI, p. 210, registro 804058.

95 Semanario Judicial de la Federación, Sexta Época, instancia: Pleno, primera parte LXIV, p. 37, registro 257974. 
Militares, Delitos cometido Por, Comisionados a la Policía FedeRAL Preventiva. Si una militar, en términos de los artículos 21 constitucional, párrafos penúltimo y último, y 10 de la Ley de la Policía Federal Preventiva, es comisionado para desempeñar un servicio en la Policía Federal Preventiva y en coordinación con el Sistema Nacional de Seguridad Pública, pero al realizar tal servicio comete un delito, debe entenderse que ese hecho criminoso lo realiza al estar en servicio y con motivos de actos de servicio militar como el artículo 57 del código castrense lo prevé, puesto que técnicamente depende del cuerpo de policía militar y administrativamente de la Secretaría de la Defensa Nacional.

Por tanto, no debe caber la menor duda en el sentido de que si un militar en ejercicio de sus funciones o con motivo de ellas comete un delito, sin importar que lo haga con la complicidad de un civil o en perjuicio de éste, debe ser juzgado por los tribunales militares, de acuerdo a lo establecido por el artículo 13 de la Constitución, el artículo 57 del Código de Justicia Militar y la interpretación del Poder Judicial de la Federación.

El 23 de noviembre de $2009^{96}$ la Corte Interamericana de Derechos Humanos sancionó al Estado mexicano y le ordenó realizar modificaciones legislativas para limitar el fuero militar. Antes de la sentencia ya en numerosas ocasiones instancias del Sistema Interamericano de Derechos Humanos y de la ONU habían recomendado al Estado mexicano restringir el fuero de guerra a cuestiones estrictamente relacionadas con la disciplina militar. Asimismo, la Comisión Nacional de los Derechos Humanos acreditó violaciones a derechos humanos por parte de los militares en diversos casos. ${ }^{97}$

96 Cfr. Corte IDH. Caso Radilla Pacheco vs. México. Excepciones Preliminares, Fondo, Reparaciones y Costas. Sentencia del 23 de noviembre de 2009. Serie C, núm. 209.

97 Por citar algunos, la Comisión Nacional de los Derechos, emitió las siguientes Recomendaciones con su respectivo número de 2007 a 2010: 37/2007, Sobre el caso de 14 mujeres víctimas de atentados a su integridad personal y libertad sexual y otros por parte de elementos del Ejército Mexicano, en la zona de tolerancia de Castaños, Coahuila, emitida el 21 de septiembre de 2007; 38/2007, Sobre los hechos ocurridos, los días 2, 3 y 4 de mayo de 2007, en los municipios de Nocupétaro, Carácuaro y Huetamo, en el estado de Michoacán, emitida el 21 de septiembre de 2007; 39/2007, Sobre los hechos de violencia ocurridos, el día 7 de mayo de 2007, en la ciudad de Apatzingán, en el estado de Michoacán, emitida el 21 de septiembre de 2007; 40/2007, Sobre el caso de la familia Esparza Galaviz y otros, en el municipio de Sinaloa de Leyva, en el estado de Sinaloa, emitida el 21 de septiembre de 2007; 29/2008, Sobre el caso del señor José Fausto Gálvez Munguía; 30/2008, Sobre el caso del señor Óscar Cornejo Tello, en el municipio de Morelia, estado de Michoacán; 31/2008, Sobre el caso del señor Fausto Ernesto Murillo Flores, en el municipio de Naco, estado de Sonora; 32/2008, Sobre el caso del señor Jesús 
Picazo Gómez; 33/2008, Sobre el caso del señor Antonio Paniagua Esquivel, en el municipio de Tanhuato, en el estado de Michoacán; 34/2008, Sobre el caso del menor Víctor Alfonso de la Paz Ortega y del joven Juan Carlos Peñaloza García, en el municipio de Huetamo, en el estado de Michoacán; 35/2008, Sobre el caso de los señores Sergio Meza Varela y José Antonio Barbosa Ramírez; 36/2008, Sobre los hechos suscitados el día 26 de marzo de 2008, en la Comunidad de "Santiago de los Caballeros", en el municipio de Badiraguato, estado de Sinaloa, emitidas el 11 de julio de 2008; 57/2008, Caso de la explosión en el Municipio de Nadadores, Coahuila; 60/2008, Caso de tortura de A1; 67/2008; Sobre el caso de tortura de A1 Y A2; 13/2009, Sobre el caso de los señores Ausencio González Gómez, Felipe Nery Marmolejo Muñoz, Erika Yazmín Pérez Martínez y Karen Esperanza Pérez Martínez; 15/2009, Sobre el caso de los señores César Antonio Gómez, Arturo Sotelo González y Raúl Palacios Campos; 18/2009, Sobre el caso de los señores Rodolfo Sandoval García y Sergio Huerta Tena, en el municipio de La Huacana, Michoacán; 28/2009, Sobre el caso del señor Miguel Ángel González González; 31/2009, Sobre el caso del señor José Carrasco Soto; 33/2009, Sobre el caso de los señores Adrián López Hernández, Saúl López Hernández y Silvia Analuisa Sentíes Lucio; 37/2009, Sobre el caso del señor Jaime Hernández Chávez, en la Comunidad de Antúñez, Municipio de Paracuaro, Michoacán; 41/2009, Sobre el caso de los señores Juan Ramón Castillo Grajeda, Arnulfo Anaya Cardoza y Luis Carlos Pérez Chávez; 44/2009, Sobre el caso de los señores José Luis y Carlos Guzmán Zúñiga, en Ciudad Juárez, Chihuahua; 48/2009, Sobre el caso del señor Román García Hernández, en el municipio de San Dionisio Ocotepec, Tlacolula, en el estado de Oaxaca; 52/2009, Sobre el caso de los señores Manuel Acosta Villarreal, Sinhué Samaniego Osorio, Jesús Arnoldo González Meza y José Alberto Rodríguez Reyes; 53/2009, Sobre el caso de los señores Gerardo Maximiliano Coronel del Razo, Reynol Roberto Palomo Velo y Esgar Godina Quezada; 54/2009, Sobre el caso del señor Valentín Arvilla Durán, en Ciudad Juárez, Chihuahua; 55/2009, Sobre el caso de los señores Juan Ramón Durán Robles y José Guadalupe Rivas González; 59/2009, Sobre el caso de la detención de ocho personas en el panteón de Villa Ahumada, Chihuahua; 61/2009, Sobre el caso de A1 y A2; 63/2009, Sobre el caso del señor Rubén Coxcahua Marín; 66/2009, Sobre el caso del menor JJLD; 70/2009, Sobre el caso de los señores FMN, JBC, AVE y PVE; 71/2009, Sobre el caso de los señores Ramón Ortiz Ríos, Ramón Ortiz Miranda y René Canales Ortiz; 73/2009, Sobre el caso del señor Ricardo García Arroyo en Ciudad Juárez, Chihuahua; 75/2009, Sobre el caso de los señores Cecilio Vásquez Miguel, Venancio Olivera Ávila y Aurelio Ortega Pacheco, en la comunidad de Santiago Lachivía, municipio de San Carlos, distrito de Yautepec, Estado de Oaxaca; 77/2009, Sobre el caso de V1; 11/2010, Sobre el caso de tortura en agravio de V1, V2 y V3; 15/2010, Sobre el caso de trato cruel en agravio de "V1"; 19/2010, Sobre el caso de retención ilegal y tortura en agravio de V1;20/2010, Sobre el caso de los tratos crueles al menor V1;22/2010, Sobre el caso de retención injustificada y tortura en agravio de V1; 36/2010, Sobre el caso de los hechos ocurridos en agravio de los menores Martín Almanza Salazar, Brayan Almanza Salazar y otros en el estado de Tamaulipas;. 42/2010, Sobre el caso de tortura de "V1"; 43/2010, Sobre el caso del atentado a la vida de "V1",; 45/2010, Sobre el caso de la privación de la vida de Javier Francisco Arredondo Verdugo y Jorge Antonio Mercado Alonso, estudiantes del Instituto Tecnológico y de Estudios Superiores de Monterrey, campus Monterrey; 49/2010, Sobre 
De igual manera, el gobierno estadounidense ha emitido sus comentarios sobre este tema, así como Human Rights Watch, Amnistía Internacional, la asociación Miguel Agustín "Pro" Juárez, A. C, entre otros. Desde abril el gobierno federal manifestó que estaba dispuesto a revisar el fuero militar. ${ }^{98}$ Más adelante, en los primeros días del mes de agosto del año en curso la Suprema Corte de Justicia de la Nación desechó el amparo que promovió la señora Reynalda Morales, que buscaba que los militares que asesinaron a su esposo, en la comunidad de Santiago de Caballeros, Sinaloa, el 26 marzo de 2008, fueran juzgados por tribunales civiles y no por militares. En este caso, la mayoría de ministros (seis contra cinco) determinó que las víctimas u ofendidos por delitos cometidos por militares no tienen derecho a ampararse para tratar de impedir que sus agresores sean juzgados por los tribunales del Ejército. No obstante que, el ministro José Ramón Cossío Díaz, un día antes presentó un proyecto de sentencia en el sentido de amparar a la señora Morales para que los militares que presuntamente asesinaron a su esposo fueran juzgados por autoridades civiles. Para el ministro Cossío, el artículo 57 del Código de Justicia Militar es inconstitucional y que, por lo tanto, debe darse un reproche al legislador por haber establecido en 1933 un exceso al llevar el fuero militar más allá de lo que dispone el artículo 13 constitucional. ${ }^{99}$

En ese mismo mes de agosto, el ministro José Ramón Cossío Díaz consideró que el Poder Judicial de la Federación debería estar obligado a acatar la sentencia que emitió la Corte Interamericana de Derechos $\mathrm{Hu}$ manos contra México en el caso Radilla —el 23 de noviembre de 2009-, en la que se señala que los militares que cometan delitos contra civiles en sus tareas de seguridad y de combate al crimen, deben ser juzgados por civiles y no por autoridades castrenses. Dicho proyecto de sentencia del ministro Cossío fue presentado ante el Pleno de la SCJN. El origen de este

el caso de detención arbitraria, retención ilegal, incomunicación y tortura de V1, V2 y V3; 50/2010, Sobre el caso de tortura de V1 Y V2; 52/2010, Sobre el caso del señor "V"; $56 / 2010$, Sobre el caso del Señor "V", agravio a periodistas, y 57/2010, Sobre el caso de tortura en agravio de "V1", "V2", "V3" y "V4", para consultar su texto véase http://www. cndh.org. $m x /$ recomen/recomend.htm.

98 Cfr. "Gobierno federal, dispuesto a revisar fuero militar", El Universal, consultado el 13 de abril de 2010.

99 Cfr. "Los elementos de las Fuerzas Armadas que cometan delitos que afecten a la población, como los relacionados con violaciones de derechos humanos, seguirán siendo juzgados por los tribunales militares", El Universal, consultado el 11 de agosto de 2010. 
proyecto fue en respuesta a una consulta interna que hizo el presidente de dicha Corte, Guillermo Ortiz Mayagoitia, en la que pidió a sus compañeros revisar si los jueces mexicanos están obligados a cumplir las sentencias de la Corte Interamericana de Derechos Humanos, porque era la primera vez que este órgano gira una orden directa al Poder Judicial Federal mexicano. En opinión de la Corte Interamericana, la Constitución mexicana, en su artículo 13, no protege a los militares ni impide que sean llevados ante autoridades civiles. ${ }^{100} \mathrm{La}$ SCJN desechó el dictamen que presentó el ministro Cossío, se acordó retirar el tema de su agenda de discusión, y así elaborar un nuevo dictamen para revisar si la sentencia le fija al Poder Judicial de la Federación obligaciones directas que tiene que cumplir ( 8 votos contra $3)$; los ministros no fijaron fecha para volver a discutir este caso, pero dejaron abierta la posibilidad de analizar el asunto en sesiones privadas y no en públicas, como venía ocurriendo. Resalta que el argumento fue que no había ninguna norma que dijera cómo se debía acatar una sentencia de la Corte Interamericana o de algún tribunal internacional y, por tanto, no era posible que la justicia mexicana se pronunciara sobre el caso. ${ }^{101}$

Finalmente, el 18 de octubre, el Poder Ejecutivo Federal presentó a la Cámara de Senadores la Iniciativa de Decreto por el que se reforman, derogan y adicionan diversas disposiciones del Código de Justicia Militar, de la Ley Orgánica del Poder Judicial de la Federación, del Código Penal Federal, del Código Federal de Procedimientos Penales y de la Ley que Establece las Normas Mínimas sobre Readaptación Social de Sentenciados. En la exposición de motivos de dicha iniciativa se establece textualmente que es "importante precisar que la libertad personal, la integridad fisica y la vida son los bienes más preciados en nuestra sociedad, por ende, el Estado mexicano está obligado a promover y proteger el ejercicio de los derechos humanos de todo gobernado, sobre todo cuando son sus propios agentes quienes vulneran estos derechos". ${ }^{102}$

${ }^{100}$ Cfr. "El Poder Judicial de la Federación (PJF) está obligado a acatar la sentencia que emitió la Corte Interamericana de Derechos Humanos (CorteIDH) contra México en el caso Radilla — el 23 de noviembre de 2009_, en la que se señala que los militares que cometan delitos contra civiles en sus tareas de seguridad y de combate al crimen, deben ser juzgados por civiles y no por autoridades castrenses", El Universal, consultado el 27 de agosto de 2010.

${ }^{101}$ Cfr. "Corte desecha el caso Radilla", El Universal, 7 de septiembre de 2010.

${ }^{102}$ Iniciativa de decreto por el que se reforman, derogan y adicionan diversas disposiciones del Código de Justicia Militar, de la Ley Orgánica del Poder Judicial de la Fe- 
Esta exposición de motivos señala también que la Corte Interamericana de Derechos Humanos, a raíz del caso Rosendo Radilla Pacheco vs. Estados Unidos Mexicanos (23 de noviembre de 2009), ordenó a nuestro país que en un plazo razonable adopte las reformas pertinentes para compatibilizar el artículo 57 del Código de Justicia Militar con los estándares internacionales en la materia y de la Convención Americana sobre Derechos Humanos, en los términos de los párrafos 337 a 342 de la sentencia de dicha Corte sobre este caso que, a grandes rasgos, establecen la necesidad que la interpretación del artículo 13 de la Constitución mexicana debe ser coherente con los principios convencionales y constitucionales de debido proceso y acceso a la justicia; que es necesario que las interpretaciones constitucionales y legislativas referidas a los criterios de competencia material y personal de la jurisdicción militar en México se ajusten a la jurisprudencia de la Corte Interamericana de Derechos Humanos, y que no es necesario que se modifique el artículo 13 de la Constitución, sino el artículo 57 del Código de Justicia Militar.

Así, se observa que la iniciativa del gobierno federal mexicano propone la modificación del artículo 57 del Código de Justicia Militar, en el sentido de lo siguiente:

Artículo 57,...

I. ...

II. ...

a)....

Los delitos de Desaparición Forzada de Personas, Violación y Tortura, previstos en los artículos 215-A, 265 y 266 del Código Penal Federal, así como 3 y 5 de la Ley Federal para Prevenir y Sancionar la Tortura, cometidos en agravio de personas civiles, serán competencia de los Tribunales del Fuero Federal.

Cuando de las diligencias practicadas en la investigación de un delito, se desprenda la probable comisión de alguno de los contemplados en el párrafo anterior, inmediatamente el Ministerio Público Militar deberá, a través del acuerdo respectivo, desglosar la averiguación previa correspondiente precisando las constancias o las actuaciones realizadas y remitirla

deración, del Código Penal Federal, del Código Federal de Procedimientos Penales y de la Ley que Establece las Normas Mínimas sobre Readaptación Social de Sentenciados, presentada por el Poder Ejecutivo Federal, Gaceta del Senado, Primer Periodo Ordinario, núm. 161, 19 de octubre de 2010, en línea en http://www.senado.gob.mx/index.php?ver= $s p \& m n=2 \& s m=2 \& i d=5723 \& \lg =61$, consultada el 19 de octubre de 2010, p. 4. 
al Ministerio Público de la Federación. Las actuaciones que formen parte del desglose no perderán su validez, aun cuando ensu realización se haya aplicado este Código y con posterioridad el Código Federal de Procedimientos Penales.

En otro artículo de la iniciativa se pretende establecer que el militar que cometa alguno de estos tres delitos esté en una prisión militar y no civil.

A este respecto, a pesar que la propia exposición de motivos de dicha iniciativa menciona, textualmente que son la libertad personal, la integridad física y la vida los bienes más preciados en nuestra sociedad, y que por ello, el Estado mexicano está obligado a promover y proteger el ejercicio de los derechos humanos de todo gobernado, sobre todo cuando son sus propios agentes quienes vulneran estos derechos, no se incluyen el homicidio y las lesiones entre los delitos que pueden cometer los militares contra civiles para ser juzgados en tribunales ordinarios.

Además, es importante señalar que esta iniciativa propone también la modificación de varios artículos de este Código de Justicia que no solicitó dicha Corte, entre éstos los artículos 1o., 2o., 129, 450 y 482, y la adición de los artículos 49 Bis y 76 Ter de este Código. De igual manera, la reforma del artículo 50 de la Ley Orgánica del Poder Judicial de la Federación; la adición de los artículos 215 A y 215 B del Código Penal Federal; el artículo 198 del Código Federal de Procedimientos Penales, y el 3o. de la Ley que Establece las Normas Mínimas sobre Readaptación Social de Sentenciados, entre otros.

Sobre los anteriores, es conveniente señalar que con dicha iniciativa se pretende que la Policía Ministerial Militar, antes Policía Judicial Militar, tenga facultades para entrevistar a testigos útiles para descubrir la verdad; realizar todo tipo de detenciones, inspecciones personales y recoger objetos que tenga en su poder, situaciones que hoy las pueden hacer siempre y cuando los militares se encuentre acompañados por autoridades civiles y a solicitud de estos últimos.

También se le pretende facultar a dicha Policía Ministerial para catear a civiles sólo con autorización de un juez militar y si no lo hubiere acudirá al de orden federal o común. De todo ello, se puede considerar que diversos artículos de la referida iniciativa son inconstitucionales, ya que el artículo 13 de la Constitución señala que "los tribunales militares en ningún caso y por ningún motivo podrán extender su jurisdicción sobre personas que no pertenezcan al Ejército". 
De igual manera, dicha iniciativa pretende crear la figura del juez de ejecución de sentencia, que siendo militar puede modificar la sentencia de un juez civil o declarar extintas las penas o medidas de seguridad, y establecer que el militar que sea detenido o sentenciado siempre esté en una prisión militar, salvo que de manera discrecional se determine una prisión civil. También propone esta iniciativa que en las averiguaciones previas militares sólo tengan acceso el inculpado, su defensor y la víctima u ofendido o su representante legal. Para todos los demás son estrictamente reservadas. Asimismo, se intenta reformar el Código Federal de Procedimientos Penales en el sentido de establecer que los militares que cometan delitos contra la salud no estén en prisiones especiales.

Finalmente, el fuero de militar es una realidad jurídica en México. No hay lugar a dudas que, bajo la interpretación que la SCJN tiene respecto del artículo 57 del Código de Justicia Militar, si un elemento militar comete un delito del orden común o federal en el ejercicio de sus funciones, o con motivo de éstas, es juzgado por los tribunales militares. Sin embargo, hoy en día son diversas las tendencias en esta materia, existe un amplio abanico de éstas y una sentencia de la Corte Interamericana de Derechos Humanos, por lo que es necesario que se estudien las mismas y se vea la mejor forma de transitar hacia una reinterpretación constitucional del fuero militar en el marco del Estado democrático.

Sin embargo, en junio y julio de 2011 ocurren dos hechos sin precedentes. El 10 de junio de ese año se reforma el artículo 1 de la Constitución para establecer lo siguiente:

En los Estados Unidos Mexicanos todas las personas gozarán de los derechos humanos reconocidos en esta Constitución y en los tratados internacionales de los que el Estado Mexicano sea parte, así como de las garantías para su protección, cuyo ejercicio no podrá restringirse ni suspenderse, salvo en los casos y bajo las condiciones que esta Constitución establece.

Las normas relativas a los derechos humanos se interpretarán de conformidad con esta Constitución y con los tratados internacionales de la materia favoreciendo en todo tiempo a las personas la protección más amplia.

Todas las autoridades, en el ámbito de sus competencias, tienen la obligación de promover, respetar, proteger y garantizar los derechos humanos de conformidad con los principios de universalidad, interdependencia, indivisibilidad y progresividad. En consecuencia, el Estado deberá prevenir, 
investigar, sancionar y reparar las violaciones a los derechos humanos, en los términos que establezca la ley. ${ }^{103}$

Por otra parte, el 11 de julio 2011, la Suprema Corte de Justicia de la Nación resolvió que el fuero militar no es válido para soldados acusados de violar derechos humanos, por lo que los militares señalados como responsables de delitos contra civiles serán procesados por jueces en esta materia y no por el fuero militar. Tal resolución fue por unanimidad del pleno de dicha Corte. Lo anterior, fue al analizar la sentencia de la Corte Interamericana de Derechos Humanos sobre la desaparición forzada de Rosendo Radilla en los años setenta y, para ello, estableció que el fuero militar no podrá conocer de los delitos cometidos contra civiles, como se llevaba a cabo de forma histórica, y puntualiza que los actos contra la disciplina militar que prevé el Código de Justicia Militar no operan para los casos en los que un integrante de las Fuerzas Armadas viole derechos de personas que no sean militares. Así, en casos futuros, todos los jueces del país deben restringir el fuero militar en los delitos presuntamente cometidos por militares contra civiles. Tal resolución obedece a las recientes modificaciones a la Constitución en materia de derechos humanos, en particular a su artículo primero, a fin de que situaciones en las que se vulneren derechos humanos de personas, no intervenga la justicia militar. Finalmente, la SCJN aclara que si llegase a existir contradicción de criterios entre tribunales civiles y militares por la resolución de un caso, será ella misma la que resuelva el conflicto de competencia.

\section{CONCLUSIONES Y PERSPECTIVAS}

Desde el punto de vista histórico, las doctrinas jurídico-militares se han clasificado en tres grupos: la francesa, la germana, y la intermedia o italiana. Sin embargo, ha surgido un cuarto grupo en donde sólo se establecen algunos delitos que, cometidos por militares, puedan ser llevados a tribunales ordinarios.

La tendencia es que los tribunales militares sean reducidos sólo a garantizar la disciplina y función militar, respetando los derechos fundamentales

${ }^{103}$ Cfr. Diario Oficial de la Federación, del 10 de junio de 2011 que contiene el Decreto por el que se modifica la denominación del capítulo i del título primero y reforma diversos artículos de la Constitución Política de los Estados Unidos Mexicanos. 
de los militares como cualquier persona. La postura general sugiere que los delitos que cometan éstos deben ser conocidos por tribunales ordinarios (fuero común y fuero federal), así como sucede con cualquier servidor público y demás habitantes del país, con el propósito de respetar el principio de igualdad ante la ley, característica de un Estado de Derecho, liberal o moderno.

Otra idea, y ya respecto de los militares que comenten delitos militares, se inclina por establecer que por arriba de la jurisdicción militar se instale en el Poder Judicial una Sala Militar, compuesta incluso de militares y con competencia para resolver determinados recursos. Esto si se mantiene sólo la jurisdicción militar relacionada con los valores y el cumplimiento de la disciplina militar. Por ejemplo, esta situación está establecida en España, en donde la Sala está integrada por cuatro magistrados ordinarios o civiles y por cuatro miembros del cuerpo jurídico militar.

En Colombia, país que tiene también problemas de narcotráfico, su Constitución establece, como lo hace México, que en ningún caso los civiles podrán ser investigados o juzgados por la justicia penal militar, y a partir de finales de 2010, estableció que habrá delitos que no se relacionan en ningún caso con el servicio activo, los cuales son los siguientes: tortura, genocidio, desaparición forzada, de lesa humanidad o aquellos que atenten contra el derecho internacional humanitario entendidos en los términos definidos en convenios y tratados internacionales ratificados por Colombia, ni las conductas que sean abiertamente contrarias a la función constitucional de la Fuerza Pública y que por su sola comisión rompan el nexo funcional del agente con el servicio.

En México, el gobierno federal mexicano presentó al Congreso la Iniciativa de Decreto por el que se reforman, derogan y adicionan diversas disposiciones del Código de Justicia Militar, de la Ley Orgánica del Poder Judicial de la Federación, del Código Penal Federal, del Código Federal de Procedimientos Penales y de la Ley que Establece las Normas Mínimas sobre Readaptación Social de Sentenciados. Por ello, no es exclusivamente una iniciativa sobre el fuero militar, sino una Reforma Penal Militar. Su exposición de motivos establece que es "importante precisar que la libertad personal, la integridad física y la vida son los bienes más preciados en nuestra sociedad...", sin embargo, a pesar de que se está consciente de que entre los bienes preciados está la vida y la integridad física, la propuesta de modificación del artículo 57 del Código de Justicia Militar no considera los delitos de homicidio y lesiones que pueden cometer los militares 
contra civiles para ser juzgados en tribunales ordinarios. Además, el militar que cometa alguno de los tres delitos (violación, desaparición forzada de personas y tortura) estará en una prisión militar y no civil. Se pretende también que la Policía Ministerial Militar tenga facultades para entrevistar a testigos útiles para descubrir la verdad; realizar todo tipo de detenciones, inspecciones personales y recoger objetos que tenga en su poder, situaciones que hoy las pueden hacer siempre y cuando los militares se encuentre acompañados por autoridades civiles y a solicitud de estos últimos. También se le pretende facultar a dicha Policía Ministerial para catear a civiles sólo con autorización de un juez militar y si no lo hubiere acudirá al de orden federal o común. De todo ello, se puede considerar que diversos artículos de la referida iniciativa son inconstitucionales, ya que el artículo 13 de la Constitución señala que "los tribunales militares en ningún caso y por ningún motivo podrán extender su jurisdicción sobre personas que no pertenezcan al Ejército".

De tal forma, actualmente en México prevalece una interpretación constitucional autoritaria respecto del fuero militar, pero que requiere de una discusión seria para que se garantice el respecto a los derechos fundamentales y la división del poder.

Hoy en día son diversas las tendencias en esta materia, existe un amplio abanico de éstas y sentencias de la Corte Interamericana de Derechos Humanos, por lo que es necesario que se estudien las mismas y se vea la mejor forma de transitar hacia una reinterpretación constitucional del fuero militar en el marco del Estado democrático. Para la sociedad lo importante es que se le garantice el respeto a sus derechos fundamentales y no la restricción de éstos. En ese sentido, en México, a partir de junio y julio de 2011, con la reforma al artículo 1o. de la Constitución y con el último criterio de la SCJN, se da esa nueva reinterpretación del fuero militar en México en el marco de la sentencia que emitió la Corte Interamericana de Derechos Humanos por la desaparición de Radilla Pacheco durante la llamada "Guerra Sucia", en donde se condenó al Estado mexicano a adoptar las medidas necesarias para que este acto no vuelva a cometerse y se privilegie la protección a los derechos humanos. ${ }^{104}$

${ }^{104}$ Cfr. http://www.eluniversal.com.mx, consultado el 12 de julio de 2011. 


\section{BIBLIOHEMEROGRAFÍA}

BAlConi Turcios, Julio Arnoldo, "Propuesta de reforma al artículo 546 del Código Procesal Penal", Los tribunales militares y la Constitución, 3-9, Colección Cuadernos de Derechos Humanos, Procurador de los Derechos Humanos, Guatemala, 1996.

BUSQUETS, Julio, "Las Fuerzas Armadas en la transición española", en Sistema, Revista de Ciencias Sociales, Madrid, núm. 93, noviembre de 1989.

CABRERA VÁzQUEZ, Juan, "Fundamentación jurídica del fuero de guerra", Boletín Jurídico Militar, México, t. X, núms. 1 y 2, México, enerofebrero de 1944.

CALDERÓn SERRANO, Ricardo, "El fuero de guerra", Criminalia. Revista de Ciencias Penales, México, año VII, núm. 12, agosto de 1941.

CAlnaCASCO SANTAMaría, Carlos, "El ministerio público como institución del fuero de guerra", Revista Mexicana de Procuración de Justicia, México, vol. 1, núm. 1, febrero de 1996.

CERDAS CRUZ, Rodolfo y NiETO LoAiza, RAFAel (comps.), Estudios Básicos de Derechos Humanos I, San José, Costa Rica, Instituto Interamericano de Derechos Humanos, 1994.

Dirección DE InFormación DE LA Policía NACiOnAl DEl Perú, “¿Qué es el Fuero Militar Policial?", Boletín Policía Nacional del Perú, año 1-2010, en línea en http://www.pnp.gob.pe/boletin/conteudo_1/csjm. html, consultado el 21 de octubre de 2010.

Diario Oficial de la Federación, del 10 de junio de 2011 que contiene el Decreto por el que se modifica la denominación del Capítulo I del Título Primero y reforma diversos artículos de la Constitución Política de los Estados Unidos Mexicanos.

DonaYre Montesinos, Christian, "Quién debe juzgar a los miembros de las Fuerzas Armadas en Perú", Iter Criminis. Revista de Ciencias Penales, México, núm. 5, 2006.

El Universal, "Corte desecha el caso Radilla", consultado 7 de septiembre de 2010.

El Universal, "El Poder Judicial de la Federación (PJF) está obligado a acatar la sentencia que emitió la Corte Interamericana de Derechos $\mathrm{Hu}-$ manos (CorteIDH) contra México en el caso Radilla - el 23 de noviembre de 2009 - , en la que se señala que los militares que cometan delitos contra civiles en sus tareas de seguridad y de combate al crimen, deben 
ser juzgados por civiles y no por autoridades castrenses", consultado el 27 de agosto de 2010.

El Universal, "Gobierno federal, dispuesto a revisar fuero militar", consultado el 13 de abril de 2010.

El Universal, "Los elementos de las Fuerzas Armadas que cometan delitos que afecten a la población, como los relacionados con violaciones de derechos humanos, seguirán siendo juzgados por los tribunales militares", consultado el 11 de agosto de 2010.

EsPinosa, Alejandro Carlos, Derecho militar mexicano, México, Porrúa, 2005.

ESPONDA, Jaime, "Apuntes preliminares sobre tema de jurisdicción militar", Los tribunales militares y la Constitución, 3-9, Colección Cuadernos de Derechos Humanos, Guatemala, Procurador de los Derechos Humanos, 1996.

FERnÁndez Segado, Francisco, "La posición constitucional de las fuerzas armadas en España. Reflexiones entorno al artículo 8 de la Constitución de 1978", Revista Derecho PUC, Lima, núm. 49, diciembre de 1995.

FROMOW GARCÍA, Mario Guillermo, "El fuero militar no es un privilegio", Iter Criminis. Revista de Ciencias Penales, México, núm. 12, 2005.

Fundación Friedrich NaUmann de la República Federal de AleMANIA, Función del ejército en una sociedad democrática, Guatemala, 1995.

GARCÍA LAGUARDiA, Jorge Mario, "Los tribunales militares y la Constitución", Los tribunales militares y la Constitución, 3-9, Colección Cuadernos de Derechos Humanos, Procurador de los Derechos Humanos, Guatemala, 1996.

GONZÁLEZ LICEA, Genaro, "Reflexiones sobre fuero de guerra y seguridad nacional de cara al siglo XXI", IDPF Revista del Instituto Federal de Defensoría Pública, México, núm. 3, junio de 2007.

GonZÁlez OropezA, Manuel, "El Fuero Militar en México: la injusticia de las Fuerzas Armadas, Revista Lex, México, junio de 2006.

HERVADA, Javier y ZuMAQUERO, José M., Textos internacionales de derechos humanos, Pamplona, Universidad de Navarra, 1978, http://www. eluniversal.com.mx, consultado el 12 de julio de 2011.

Iniciativa de decreto por el que se reforman, derogan y adicionan diversas disposiciones del Código de Justicia Militar, de la Ley Orgánica del 
Poder Judicial de la Federación, del Código Penal Federal, del Código Federal de Procedimientos Penales y de la Ley que Establece las Normas Minimas sobre Readaptación Social de Sentenciados, presentada por el Poder Ejecutivo Federal, Gaceta del Senado, Primer Periodo Ordinario, núm. 161, 19 de octubre de 2010, en línea en http://www. senado.gob. $m x /$ index.php? ver $=s p \& m n=2 \& s m=2 \& i d=5723 \& \lg =61$, consultada el 19 de octubre de 2010.

GRAF VON BAUDISSIN, Wolf, "Prólogo", Fuerzas Armadas y democracia, Buenos Aires, El Cid Editor, 1982.

Jurisprudencia Contenciosa de la Corte IDH, Fuero Miliar, desde la Sentencia del 17 de septiembre de 1997 al 31 de agosto de 2010.

LARA VILLA, Samuel, "Las fuerzas armadas mexicanas en el proyecto inaplazable de Reforma del Estado", Revista del Senado de la República, México, vol. 5, núm. 6, julio-septiembre de 1999.

Ley Orgánica 4/1987, de 15 de julio, de la Competencia y Organización de la Jurisdicción Militar (publicada en el BOE, del 18 de julio de 1987; entrada en vigor: 10. de mayo de 1988).

Ley Orgánica 13/1985, del 9 de diciembre, de Código Penal Militar (publicada en el $B O E$, del 11 de diciembre de 1985; entrada en vigor: 10. de junio de 1986).

Ley Orgánica 5/2005, del 17 de noviembre, de la Defensa Nacional (publicada en el $B O E$, del 18 de noviembre de 2005; entrada en vigor: 8 de diciembre de 2005).

MARTí SÁnCHEZ, Sylvia, "Sinopsis del artículo 117 de la Constitución española", Congreso de los Diputados, diciembre de 2003, en línea en http://www.congreso.es/consti/constitucion/indice/sinopsis/sinopsis. jsp? art $=117 \&$ tipo $=2$, consultado el 10 de octubre de 2010 .

MENCHÚ TUM, Rigoberta, "Fundamentación jurídica en el caso de la masacre de Xaman", Los tribunales militares y la Constitución, 3-9, Colección Cuadernos de Derechos Humanos, Guatemala, Procurador de los Derechos Humanos, 1996.

Mera FigueroA, Jorge, "La Modernización de la Justicia Militar un Desafío Pendiente", pp. 6 y 7, en línea en http://www.ssg.cl/justicia/documentos/ mera_la_modernizacion_de_la_justicia_militar.pdf?PHPSESSID $=064$ ea 95572a300405fd9acbff0a $\overline{5} 0 \mathrm{a} \overline{75}$, consultado el 21 de octubre de 2010.

Procurador De los Derechos Humanos, "Decreto número 41-96", Los tribunales militares y la Constitución, 3-9, Colección Cuadernos 
de Derechos Humanos, Guatemala, Procurador de los Derechos Humanos, 1996.

Rebollo Moreno, Enrique, "Fuero de guerra", Boletín Jurídico Militar, México, tomo XIX, núms. 9 y 10, septiembre octubre de 1955.

Recomendaciones de la Comisión Nacional de los Derechos Humanos, http://www.cndh.org. $m x /$ recomen/recomend.htm.

RoMero APIS, José Elías, "Génesis y vigencia del Artículo 13 en el constituyente de 1917", Revista del Ejército y Fuerza Aérea Mexicanos. El fuero de guerra, su constitucionalidad, México, julio de 1999.

SAuCedo LóPez, Antonio, Los tribunales militares en México, México, Trillas, 2002.

—- Teoría jurídica del Ejército y sus lineamientos constitucionales, México, UNAM, Instituto de Investigaciones Jurídicas, 2002.

SCHAPOSNIK, Eduardo C., La democratización de las Fuerzas Armadas venezolanas, Caracas, 1985.

Semanario Judicial de la Federación, Sexta Época, Pleno, primera parte XLI, p. 210, registro 804058.

SENADO DE LA REPÚBliCA, Documentos históricos constitucionales de las Fuerzas Armadas Mexicanas, México, 1965-1966.

Semanario Judicial de la Federación, Sexta Época, Pleno, primera parte L, p. 22, registro 258142.

Semanario Judicial de la Federación, Sexta Época, Pleno, primera parte LXIV, p. 37, registro 257974.

SCJN, Serie Grandes temas del constitucionalismo mexicano. El fuero, México, 2005. 